\title{
Exploring Diverse-Ring Analogues on Combretastatin A4 (CA-4) Olefin as Microtubule-Targeting Agents
}

\author{
Ming-Yu Song ${ }^{1,+}{ }^{+}$Qiu-Rui He ${ }^{1,+}$, Yi-Lin Wang ${ }^{2}$, Hao-Ran Wang ${ }^{2}$, Tian-Cheng Jiang ${ }^{3}$, \\ Jiang-Jiang Tang ${ }^{1, *}$ and Jin-Ming Gao ${ }^{1}$ \\ 1 Shaanxi Key Laboratory of Natural Products \& Chemical Biology, College of Chemistry \& Pharmacy, \\ Northwest A\&F University, Yangling 712100, China; mingyusong@nwsuaf.edu.cn (M.-Y.S.); \\ heqiurui@nwsuaf.edu.cn (Q.-R.H.); jinminggao@nwsuaf.edu.cn (J.-M.G.) \\ 2 College of Innovation and Experiment, Northwest A\&F University, Yangling 712100, China; \\ yilinwang1997@hotmail.com (Y.-L.W.); 2015014887@nwafu.edu.cn (H.-R.W.) \\ 3 College of Food Science and Engeering, Northwest A\&F University, Yangling 712100, China; \\ jtc990329@163.com \\ * Correspondence: tangjiang11@nwsuaf.edu.cn; Tel.: +86-2987-09-2662 \\ + These authors contributed equally to this work.
}

Received: 15 February 2020; Accepted: 4 March 2020; Published: 6 March 2020

\begin{abstract}
Combretastatin-4 (CA-4) as a tubulin polymerization inhibitor draws extensive attentions. However, due to its weak stability of cis-olefin and poor metabolic stability, structure modifications on cis-configuration are being performed. In this work, we constructed a series of novel CA-4 analogues with linkers on olefin containing diphenylethanone, cis-locked dihydrofuran, $\alpha$-substituted diphenylethanone, cyclobutane and cyclohexane on its cis-olefin. Cytotoxic activity of all analogues was measured by an SRB assay. Among them, compound $\mathbf{6 b}$, a by-product in the preparation of diphenylethanone analogues, was found to be the most potent cytotoxic agents against HepG2 cells with $\mathrm{IC}_{50}$ values of less than $0.5 \mu \mathrm{M}$. The two isomers of $\mathbf{6 b}$ induced cellular apoptosis tested by Annexin V-FITC and propidium iodide (PI) double staining, arrested cells in the G2/M phase by PI staining analysis, and disrupted microtubule network by immunohistochemistry study in HepG2 cells. Moreover, $\mathbf{6 b}-(\boldsymbol{E})$ displayed a dose-dependent inhibition effect for tubulin assembly in in vitro tubulin polymerization assay. In addition, molecular docking studies showed that two isomers of $\mathbf{6 b}$ could bind efficiently at colchicine binding site of tubulin similar to CA-4.
\end{abstract}

Keywords: combretastatin-4; tubulin polymerization; diphenylethanone; cis-locked dihydrofuran; $\alpha$-substituted diphenylethanone; cyclobutane; cyclohexane

\section{Introduction}

The natural product combretastatin A-4 (CA-4, Figure 1) was first isolated from the South African tree Combretum caffrum in 1989 [1,2] and was serendipitously discovered in 1998 by strongly blocking the polymerization of tubulin with the colchicine binding site [3]. CA-4 and its water-soluble prodrugs such as CA-4P (fosbretabulin and zybrestat) [4] and AVE8062 (ombrabulin) [5] have entered clinical trials for the treatment of anaplastic thyroid cancer and other solid tumors in both USA and Europe [6]. Due to its small molecular weight and simple structure, an impressive number of synthetic research was carried out over the past decades [7-10].

The structure-activity relationships (SARs) have made clearly important features of maintaining the tubulin interaction for CA-4. The presence of 3,4,5-trimethoxy groups at ring-A, 4'-methoxy group at ring-B and cis-configuration of olefin are the indispensability for inhibiting tubulin assembly [11]. Nevertheless, the Z-restricted configuration can rapidly convert into 100-fold less 
active trans-isomerization under the conditions of suffering from heat, light and protic media [12]. Meanwhile, the poor metabolic stability caused by the olefinic bridge and the weak water solubility of CA-4 resulted in restrictions for its exploitation [13]. Thus, an extensive focus of research was directed towards the rational modifications of the unstable olefinic bond as the main pursued strategy. Various olefinic linkers including silicon [14], butadiene [15], cyclopropane [16], cyclopropyl [17], chiral-lactam [18], furan [19], furazan [20], imidazole [21], 2,3-diarylthiophene [22], isoxazole and terphenyl [23], triazoles [24,25], thiazole [26,27] and 1,2,4-triazolo-4,3-b-pyridazines [28] has unveiled novel agents endowed with cytotoxic activity.

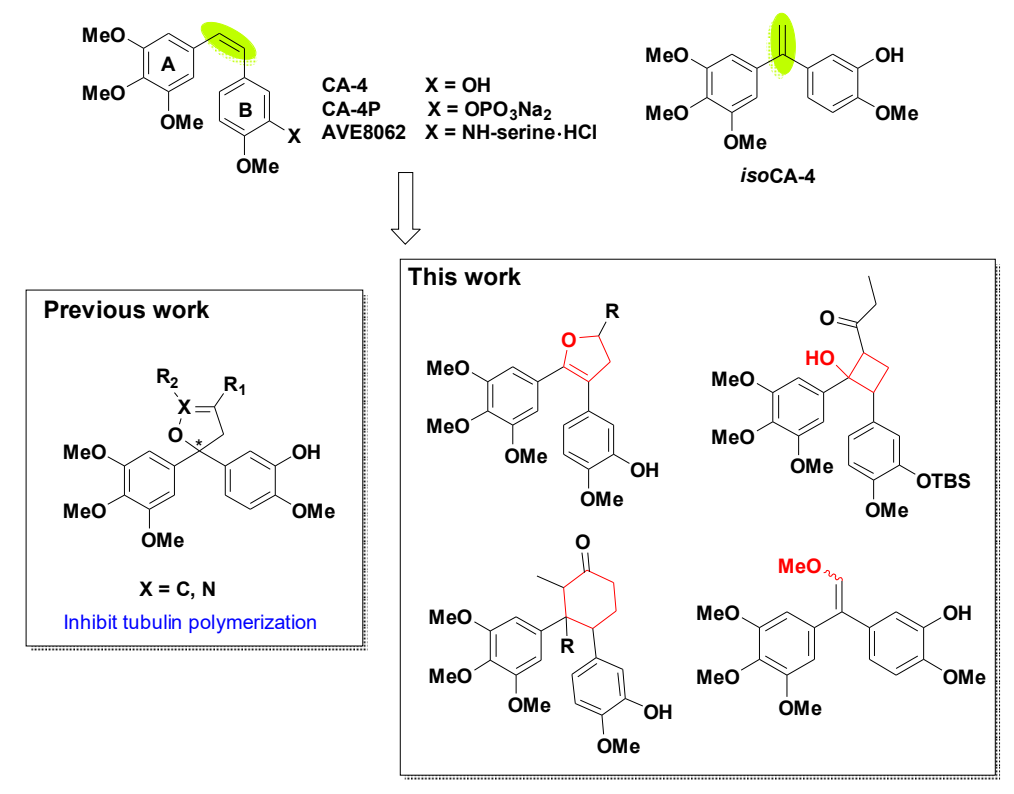

Figure 1. The structures of CA-4 and synthetic prodrugs, isoCA-4 and designed analogues.

Isocombretastatin A-4 (isoCA-4, Figure 1), an unexpectedly synthesized isomer of CA-4 found by Alami [29], exhibited a very strong inhibition on cancer cell growth similar to that of CA-4. The synthetic method is simple without the control of cis-configuration [30,31]. The Alami group have completed plentiful studies on the modification of 1,1-diaryl double bond scaffold using naphthenic [32], naphthalene [33], arylchromenes [34], azaisoerianin [35], arylbenzoxepins [36], etc. In our previous works [37], dihydrofuran and dihydroisoxazole analogues of isoCA-4 were prepared through [3+2] reactions and could inhibit tubulin polymerization.

In our endeavor aiming at finding novel potential rigid analogues of CA-4 and isoCA-4, we hypothesized that the replacement of the unstable olefinic bond of CA-4 with cis-locked dihydrofuran, $\alpha$-substituted, cyclobutane and cyclohexane nucleuses (Figure 1) could be a good strategy to unravel a novel class of antitubulin agents. Indeed, different number rings are widely used as a molecular scaffold in natural products and medicinal chemistry because of their favorable pharmacokinetic features and their ability to act as a privileged structure when properly decorated. In this work, we present the synthesis through the modification of olefin scaffold with diphenylethanone, cis-locked dihydrofuran, $\alpha$-substituted diphenylethanone, cyclobutane and cyclohexane. Subsequently, their cytotoxic activity was evaluated against HepG2 cells, and the most potent cytotoxic compound was selected to carry out mechanism studies including apoptosis, cell cycle analysis, immunohistochemistry, tubulin polymerization assay and molecular docking. 


\section{Results and Discussion}

\subsection{Chemistry}

5-bromo-2-methoxyphenol was firstly converted into the key intermediate 4 by four steps in total $65 \%$ yield referred to our previous report [37]. Subsequently, 4 was oxidized with rearrangement of olefinic bond through iodobenzene acetate $\left(\mathrm{PhI}(\mathrm{OAc})_{2}\right)$ to afford the key compound 5a. The synthetic conditions were optimized in Scheme 1 . In the synthesis of $\mathbf{5 a}, \mathrm{NaHSO}_{4}$ was used as the initial activator of $\mathrm{PhI}(\mathrm{OAc})_{2}$. However, the conversion of 4 was always very low in the presence or absence of solvent as shown in entry 1 and 2, and the yield of $5 \mathbf{a}$ was only about $10 \%$ when the ratio of $4, \mathrm{PhI}(\mathrm{OAc})_{2}$ and $\mathrm{NaHSO}_{4}$ was 1:1:1. As the ratio of $\mathrm{PhI}(\mathrm{OAc})_{2}$ and $\mathrm{NaHSO}_{4}$ continued to increase, the conversion rate of 4 was indeed greatly improved when the reaction adopted $\mathrm{MeCN}-\mathrm{H}_{2} \mathrm{O}(5: 1)$ as the solvent in entry 3 and 4 . When both of $\mathrm{PhI}(\mathrm{OAc})_{2}$ and $\mathrm{NaHSO}_{4}$ reached 2 equivalent (entry 5), 4 could react completely, but the yield of 5 a was still only about $10 \%$ or even lower. After the $\mathrm{NaHSO}_{4}$ was replaced with $\mathrm{H}_{2} \mathrm{SO}_{4}$ (50\% methanol solution), the reaction was completed with a $61 \%$ yield at $-20{ }^{\circ} \mathrm{C}$, while the ratio of 4 , $\mathrm{PhI}(\mathrm{OAc})_{2}$, and $\mathrm{H}_{2} \mathrm{SO}_{4}$ was 1:1.1:1.1 in entry 6 . Accidentally, a by-product 6a was given under the condition of entry 6 with $30 \%$ yield, and $\mathbf{6 b}$ was prepared from $\mathbf{6 a}$ using tetrabutyl ammonium fluoride (TBAF) to remove the protection group in $95 \%$ yield. To the formation of the by-product $6 \mathrm{a}, \mathrm{MeOH}$ may attack the intermediate of $\mathrm{PhI}(\mathrm{OAc})_{2}$ and $\mathrm{H}_{2} \mathrm{SO}_{4}$ in reaction kinetics and through following elimination reaction to trigger the formation of $6 \mathbf{a}$. The possible reaction mechanism was shown as Scheme S1 in the Supplementary Material. Furthermore, the HPLC analysis and ${ }^{13} \mathrm{C}$ NMR spectrum of $\mathbf{6 b}$ revealed that the ratio of $(Z) /(E)$ isomers was about 1:1. To explore biological activities of different isomers, $\mathbf{6 b}-(Z)$ and $\mathbf{6 b}-(E)$ were separated by preparative HPLC. The assignment of the olefin geometry of $\mathbf{6 b}-(\mathbf{Z})$ was determined using NOESY NMR experiments. Specifically, NOESY signals of $\mathbf{6 b}-(\mathbf{Z})$ were readily apparent between the proton of phenyl ring and the proton attached to the olefin in Figure 2 (see Supplementary data).
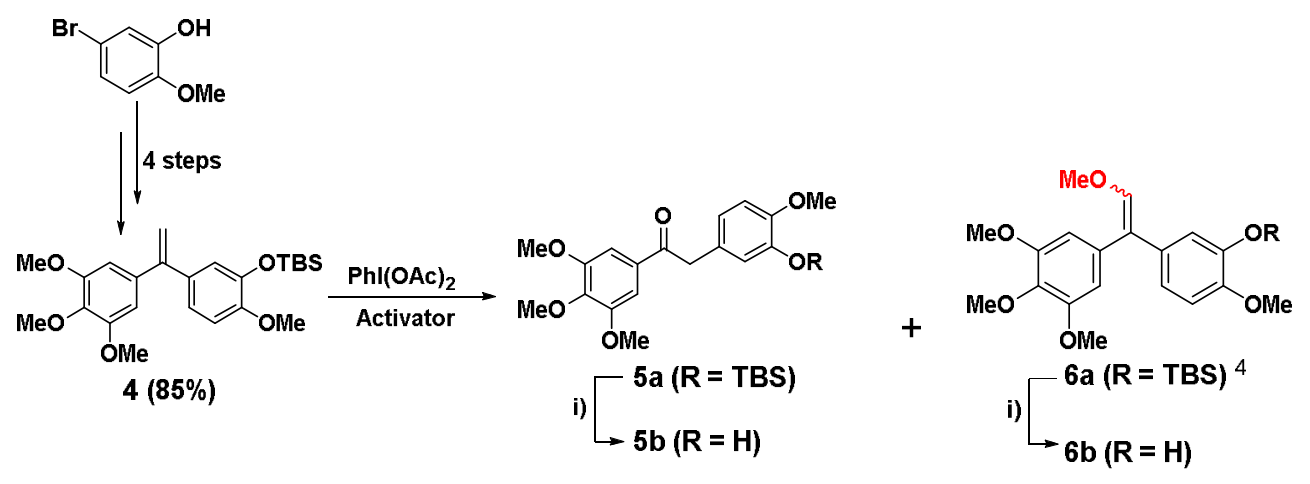

\begin{tabular}{cccccc}
\hline Entry & Activator & Equivalent & Solvent & Conversion (\%) & Yield (\%) of 5a \\
\hline 1 & $\mathrm{NaHSO}_{4}$ & $1: 1: 1$ & free & 30 & 10 \\
2 & $\mathrm{NaHSO}_{4}$ & $1: 1: 1$ & $\mathrm{MeCN}-\mathrm{H}_{2} \mathrm{O}^{2}$ & 25 & 8 \\
3 & $\mathrm{NaHSO}_{4}$ & $1: 1.3: 1.3$ & $\mathrm{MeCN}-\mathrm{H}_{2} \mathrm{O}$ & 88 & 12 \\
4 & $\mathrm{NaHSO}_{4}$ & $1: 1.5: 1.5$ & $\mathrm{MeCN}-\mathrm{H}_{2} \mathrm{O}$ & 90 & 10 \\
5 & $\mathrm{NaHSO}_{4}$ & $1: 2: 2$ & $\mathrm{MeCN}$ & 100 & $<5$ \\
6 & $\mathrm{H}_{2} \mathrm{SO}_{4}{ }^{3}$ & $1: 1.1: 1.1$ & $\mathrm{MeOH}$ & 100 & 61 \\
\hline
\end{tabular}

${ }^{1}$ Equivalent represents the ratio of 4 : $\mathrm{PhI}(\mathrm{OAc}) 2$ : activator; ${ }^{2} \mathrm{MeCN}-\mathrm{H}_{2} \mathrm{O}$ is $5: 1(\mathrm{v} / \mathrm{v}) ;{ }^{3} \mathrm{H}_{2} \mathrm{SO}_{4}$ is $50 \%$ methanol solution; ${ }^{4} \mathbf{6 a}$ was obtained under the condition of the Entry 6 with $30 \%$ yield. $\mathbf{6 b}$ was prepared from $6 \mathrm{a}$ in $95 \%$ yield.

Scheme 1. Synthesis of compounds $5 a, 5 b$ and $\mathbf{6 a}, \mathbf{6 b}$. Synthetic conditions optimization of $5 a$. i) TBAF, $\mathrm{THF}, 30 \mathrm{~min}$. 


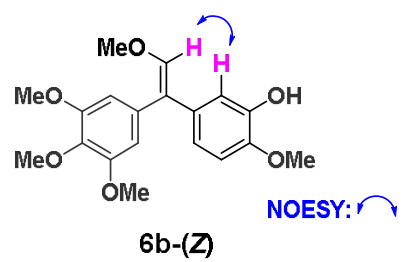<smiles>CO/C=C(/c1ccc(O)c(OC)c1)c1ccc(OC)c(OC)c1</smiles>

Figure 2. $\mathbf{6 b}-(Z)$ and $\mathbf{6 b}-(E)$ after HPLC preparation. Selected NOE correlations of $\mathbf{6 b}-(Z)$.

With $\mathbf{5 a}$ in hands, dihydrofuran analogues were prepared by [3+2] cycloaddition in Scheme 2. A free-radical reaction between $\mathbf{5 a}$ and conjugated diolefinic compounds was catalyzed by a single-electron oxidant $\mathrm{Cu}(\mathrm{OAc})_{2}$, and following by TBAF to remove the TBS group of the phenolic hydroxyl to provide the dihydrofuran $7 \mathbf{a}$ and $7 \mathbf{b}$. In this free-radical reaction, $\mathrm{Mn}(\mathrm{OAc})_{3}$ as the initial oxidant gave extremely low yield, perhaps the single-electron oxidation energy of Mn (III) (1.5 V) could still be too high for this reaction. Thus, $\mathrm{Cu}$ (II) with one-electron oxidation energy of only $0.16 \mathrm{~V}$ was employed for this reaction and the conditions were optimized by using $\mathrm{Cu}(\mathrm{OAc})_{2}$ as the catalyst and the acetophenone as the conjugated olefin. It was found that when the ratio of $5 \mathbf{a}, \mathrm{Cu}(\mathrm{OAc})_{2}$ and acetophenone was 1:3:3, 5a could react completely in $12 \mathrm{~h}$. However, a large amount of by-products would appear after $4 \mathrm{~h}$. Therefore, the optimal reaction time should be $4 \mathrm{~h}$, while the conversion rate of $5 \mathbf{a}$ was about $70 \%$, and the yield of $7 \mathbf{a}$ was $65 \%$. Using this condition, dihydrofuran compound $7 \mathbf{b}$ was also synthesized using isoprene, and the two steps yield was $45 \%$.

However, under the above condition, an addition reaction between $5 \mathbf{a}$ and pentenone occurred to give compound $8 \mathbf{a}$ with a conversion yield of $74 \%$ (Scheme 2 ). The reason that $8 \mathbf{a}$ did not cyclize into a dihydrofuran ring might be the electron-withdrawing effect of the carbonyl group. $\mathbf{8 b}$ was afforded by deprotection of the TBS group similar to the above method. Next, the structure of 1,5-dione of $8 \mathbf{a}$ gave us a new idea to synthesize cyclobutane and cyclohexane analogues of CA-4 through Aldol condensation. For example, cyclobutane analogue 9 was prepared under the conditions of LiHMDS and $\mathrm{TsCl}$ at $-78{ }^{\circ} \mathrm{C}$ in a $40 \%$ yield (Scheme 2 ).

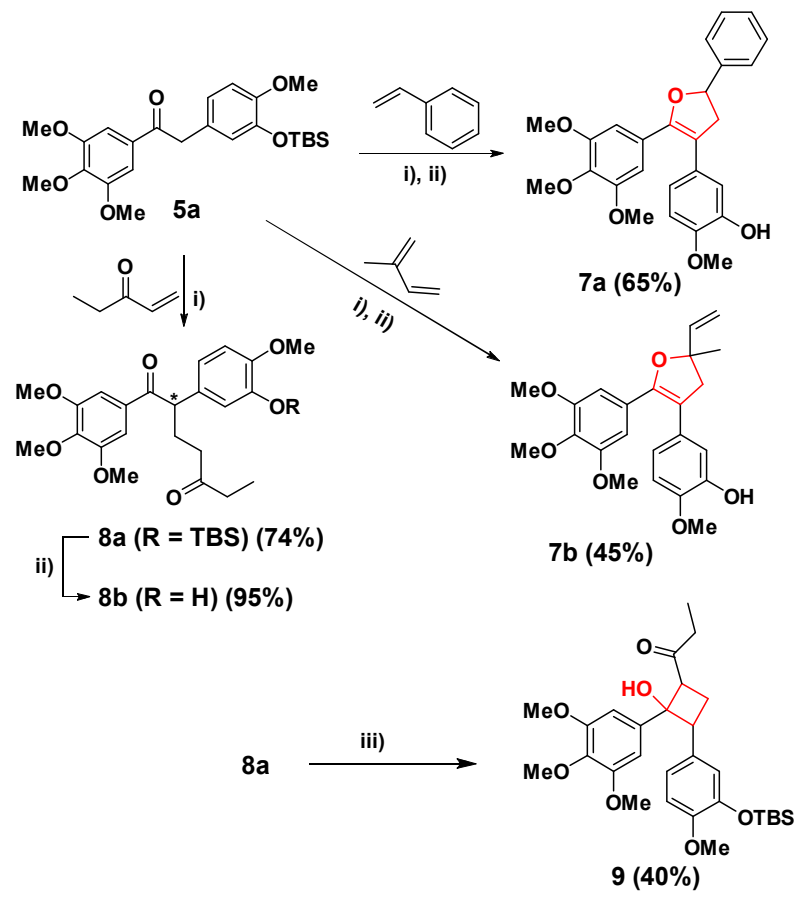

Scheme 2. Synthesis of $\mathbf{7 a}, \mathbf{7 b}, \mathbf{8 a}, \mathbf{8 b}$ and $\mathbf{9}$. Condition: i) $\mathrm{Cu}(\mathrm{OAc})_{2}, \mathrm{DCE}, 110^{\circ} \mathrm{C}, 4 \mathrm{~h}$; ii) TBAF, THF, $0.5 \mathrm{~h}$; iii) LiHMDS, $\mathrm{TsCl},-78{ }^{\circ} \mathrm{C}$. 
For synthesis of cyclohexane analogues, the Aldol condensation of 8a was not smooth due to the not very stable TBS protecting group under a strong base condition. On the one hand, strong alkalinity can promote the reaction to proceed forward. However, on the other hand, it would cause the removal of TBS under the action of too strong bases, then reduce the number of substrate and push the reverse reaction. Therefore, it is very important to choose a base with moderate alkalinity.

The condition optimization of Aldol condensation is shown in Scheme 3. At first, the reaction was performed with $\mathrm{KOH}$ in methanol under reflux, $\mathbf{8} \mathbf{a}$ was completely converted quickly, but there was no expected product $\mathbf{1 0 a}$ or $\mathbf{8 b}$ in entry 1 . Then, three inorganic bases: $\mathrm{KOH}, \mathrm{NaOH}$ and $\mathrm{LiOH}$ (entry 2-4) were selected and methanol was employed as the solvent at $0{ }^{\circ} \mathrm{C}$. After the three bases were added, the reaction occurred immediately, and 10a was obtained in the beginning period. However, $10 \mathrm{~min}$ later, the reactions of $\mathrm{KOH}$ and $\mathrm{NaOH}$ began to generate $8 \mathbf{b}$. After another $20 \mathrm{~min}$, all 10a and $\mathbf{8 a}$ were turned into $\mathbf{8 b}$. However, the reaction of $\mathrm{LiOH}$ (entry 4 ) started to generate $\mathbf{8 b}$ after $30 \mathrm{~min}$, while the conversion yield of $\mathbf{1 0 a}$ is $65 \%$. Under the action of $\mathrm{K}_{2} \mathrm{CO}_{3}$ (1 eq, entry 5), 8a could rapidly generate a mixture of $\mathbf{1 0 a}, \mathbf{8 b}$ and a little deprotected product of $10 \mathrm{a}$ at room temperature. Yet, when the temperature fell to $0{ }^{\circ} \mathrm{C}, 8 \mathbf{a}$ was completely unreactive even increasing the equivalent of $\mathrm{K}_{2} \mathrm{CO}_{3}$ to 10 eq (entry 6). NaOMe also could not make 8a react in solvent of benzene in entry 8 . In organic bases, 1,8-diazabicyclo[5.4.0]undec-7-ene (DBU) could make $8 \mathbf{a}$ to turn into $8 \mathbf{b}$ within $30 \mathrm{~min}$ at room temperature, and lithium diisopropylamide (LDA) could give a $10 \%$ yield of $10 \mathrm{a}$ at $-78{ }^{\circ} \mathrm{C}$, in entry 9 and 10, respectively. To sum up, $\mathrm{LiOH}, 0^{\circ} \mathrm{C}$, and $30 \mathrm{~min}$ were the optimized conditions with a conversion yield of $65 \%$ for $10 a$. After $10 a$ was deprotected by TBAF, a cyclohexane-based CA-4 analogue $10 \mathrm{~b}$ was obtained (Scheme 3 ).

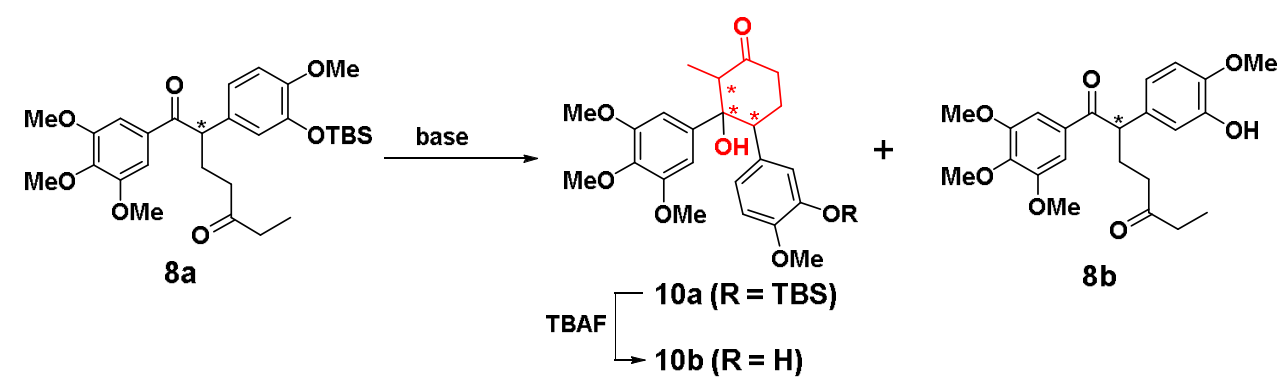

\begin{tabular}{|c|c|c|c|c|c|c|c|}
\hline \multirow{2}{*}{ Entry } & \multirow{2}{*}{ Base } & \multirow{2}{*}{ Equivalent } & \multirow{2}{*}{ Solvent } & \multirow{2}{*}{$\begin{array}{c}\text { Temperature } \\
\left({ }^{\circ} \mathrm{C}\right)\end{array}$} & \multirow{2}{*}{$\begin{array}{l}\text { Time } \\
(\min )\end{array}$} & \multicolumn{2}{|c|}{ Yield (\%) } \\
\hline & & & & & & $10 a$ & $8 b$ \\
\hline 1 & $\mathrm{KOH}$ & 10 & $\mathrm{MeOH}$ & 90 & 30 & - & - \\
\hline 2 & $\mathrm{KOH}$ & 10 & $\mathrm{MeOH}$ & 0 & 30 & - & $>95$ \\
\hline 3 & $\mathrm{NaOH}$ & 10 & $\mathrm{MeOH}$ & 0 & 30 & - & $>95$ \\
\hline 4 & $\mathrm{LiOH}$ & 10 & $\mathrm{MeOH}$ & 0 & 30 & 65 & - \\
\hline 5 & $\mathrm{~K}_{2} \mathrm{CO}_{3}$ & 1 & $\mathrm{MeOH}$ & $\mathrm{rt}$ & 30 & 20 & 15 \\
\hline 6 & $\mathrm{~K}_{2} \mathrm{CO}_{3}$ & 10 & $\mathrm{MeOH}$ & 0 & 60 & \multicolumn{2}{|c|}{ No reaction } \\
\hline 7 & $\mathrm{Na}_{2} \mathrm{CO}_{3}$ & 10 & $\mathrm{MeOH}$ & 0 & 60 & \multicolumn{2}{|c|}{ No reaction } \\
\hline 8 & $\mathrm{NaOMe}$ & 10 & Benzene & $\mathrm{rt}$ & 45 & \multicolumn{2}{|c|}{ No reaction } \\
\hline 9 & DBU & 5 & $\mathrm{CH}_{3} \mathrm{CN}$ & $\mathrm{rt}$ & 30 & - & $>95$ \\
\hline 10 & LDA & 2 & THF & -78 & 60 & 10 & - \\
\hline
\end{tabular}

Scheme 3. Synthetic conditions optimization of compound 10a.

In order to enhance the polarity and water solubility of $\mathbf{1 0 b}$, carbonyl group of $\mathbf{1 0 a}$ was reduced by sodium borohydride $\left(\mathrm{NaBH}_{4}\right)$ to a $\mathrm{HO}$ group (Scheme 4). After deprotection of the TBS group by TBAF, 11 was obtained in two steps with a 66\% yield. Moreover, LiHMDS was employed to remove

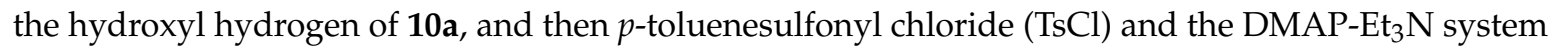
were used to eliminate the sulfonyl group. Finally, the TBS group was deprotected by TBAF to give 
another cyclohexane analogue 12 (Scheme 4). The total yield of the three steps was $28 \%$. It was noted that $\mathbf{1 2}$ was unable to react under the action of $\mathrm{NaBH}_{4}$ to afford 11.

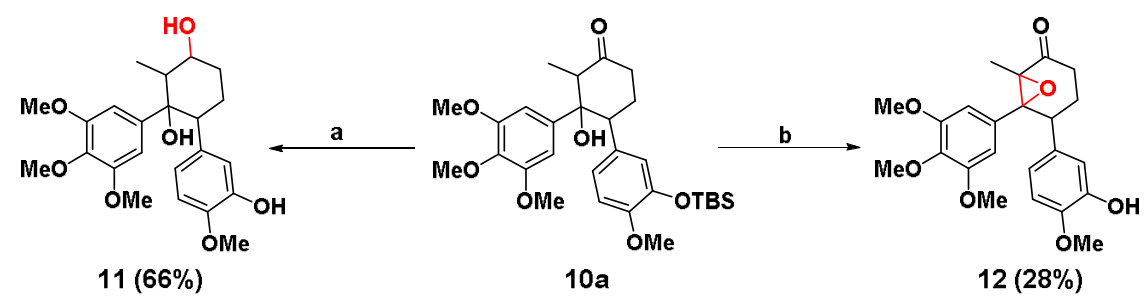

Scheme 4. Synthesis of $\mathbf{1 1}$ and 12. Condition: (a) i) $\mathrm{NaBH}_{4}, \mathrm{DCE}, 0^{\circ} \mathrm{C}, 1 \mathrm{~h}$; ii) TBAF, THF, $30 \mathrm{~min}$ and (b) i) LiHMDS, $\mathrm{TsCl},-78{ }^{\circ} \mathrm{C}$; ii) $\mathrm{Et}_{3} \mathrm{~N}$, DMAP, DMF, $80{ }^{\circ} \mathrm{C}$ and iii) TBAF, THF, $30 \mathrm{~min}$.

\subsection{Biological Activity}

New synthesized CA-4 analogues were in vitro screened for anticancer activity against HepG-2 (human liver cancer cell line) with CA-4 and isoCA-4 as reference drugs using the sulforhodamine $\mathrm{B}$ (SRB) assay [38]. The $\mathrm{IC}_{50}$ values (the concentration to cause $50 \%$ inhibition of cell viability) were summarized in Table 1. It could be seen that these CA-4 analogues diphenylethanone $\mathbf{5 b}$, cis-locked dihydrofuran analogues $\mathbf{7 a} \mathbf{7 b}, \alpha$-substituted diphenylethanones $\mathbf{8 a}, \mathbf{8 b}$, cyclobutane analogue $\mathbf{9}$, cyclohexane analogues $\mathbf{1 0 a}, \mathbf{1 0 b}$ and 11 showed weak cytotoxic activity with $\mathrm{IC}_{50}$ values over $10 \mu \mathrm{M}$. Another cyclohexane analogue 12 exhibited a good cytotoxic activity with $\mathrm{IC}_{50}$ of $3.67 \mu \mathrm{M}$, but with far less than $\mathrm{IC}_{50}$ of CA-4 and isoCA-4 $(0.013 \mu \mathrm{M}$ and $0.017 \mu \mathrm{M}$, respectively). These results suggested that introductions of ethanone, four or five or six-membered rings on the cis-double bond of CA-4 were not a good synthetic strategy for optimizing anticancer activity. However, it was worth to note that isoCA-4 analogue $6 \mathbf{b}$ displayed strongest activity with $\mathrm{IC}_{50}$ of $<0.5 \mu \mathrm{M}$ among all compounds. Notably, the $\mathrm{IC}_{50}$ results of $\mathbf{6 b}-(\mathbf{Z})$ with $\mathrm{IC}_{50}$ of $0.30 \mu \mathrm{M}$ and $\mathbf{6 b}-(\boldsymbol{E})$ with $\mathrm{IC}_{50}$ of $0.23 \mu \mathrm{M}$ on HepG2 cells indicated no obvious gap in cytotoxic activity between cis-trans isomers.

Table 1. Cytotoxic activities $\left(\mathrm{IC}_{50}\right)$ of compounds against HepG2 cells.

\begin{tabular}{cccc}
\hline Compd & IC $_{\mathbf{5 0}}(\boldsymbol{\mu M})^{\mathbf{1}}$ & Compd & IC $_{\mathbf{5 0}}(\boldsymbol{\mu M})$ \\
\hline $\mathbf{5 b}$ & $>10$ & $\mathbf{9}$ & $>10$ \\
$\mathbf{6 b}-(\mathbf{Z})$ & $0.30 \pm 0.05$ & $\mathbf{1 0 a}$ & $>10$ \\
$\mathbf{6 b -}(\boldsymbol{E})$ & $0.23 \pm 0.07$ & $\mathbf{1 0 b}$ & $>10$ \\
$\mathbf{7 a}$ & $>10$ & $\mathbf{1 1}$ & $>10$ \\
$\mathbf{7 b}$ & $>10$ & $\mathbf{1 2}$ & $3.67 \pm 0.16$ \\
$\mathbf{8 a}$ & $>10$ & $\mathrm{CA}-4$ & $0.013 \pm 0.003$ \\
$\mathbf{8 b}$ & $>10$ & isoCA-4 & $0.017 \pm 0.002$ \\
\hline
\end{tabular}

${ }^{1} \mathrm{The} \mathrm{IC}_{50}$ values represent the concentration that causes $50 \%$ inhibition of cell viability measured by SRB assay. Cells were treated with the compounds for $48 \mathrm{~h}$. All data (mean \pm SD) are the average of three determinations. HepG-2: human liver cancer cells.

Apoptosis induction is characteristic of many known anticancer agents. To determine whether the inhibition of $\mathbf{6 b}-(Z)$ and $\mathbf{6 b}-(E)$ on cell growth was related to cell apoptosis, a flow cytometric analysis by staining cells with Annexin V-FITC and propidium iodide (PI) was performed on HepG-2 cells. The result showed that treatment with $0.05 \mu \mathrm{M}$ CA-4 for $48 \mathrm{~h}$ induced $26.5 \%$ and $13.4 \%$ early and late apoptotic cells, respectively (Figure 3). Similar apoptosis induced by CA-4 has been reported previously [3]. After treatment with compounds $\mathbf{6 b}-(\mathbf{Z})$ and $\mathbf{6 b}-(E)$ at $0.3 \mu \mathrm{M}$, the early and late apoptosis rates were significantly increased from $5.0 \%$ and $3.5 \%$ (for control group) to $19.2 \%$ and $16.1 \%$ (for $\mathbf{6 b}$-(Z) group), and $24.1 \%$ and $19.4 \%$ (for $\mathbf{6 b}-(E)$ group), respectively. The results indicated that both analogues could cause cellular apoptosis. 


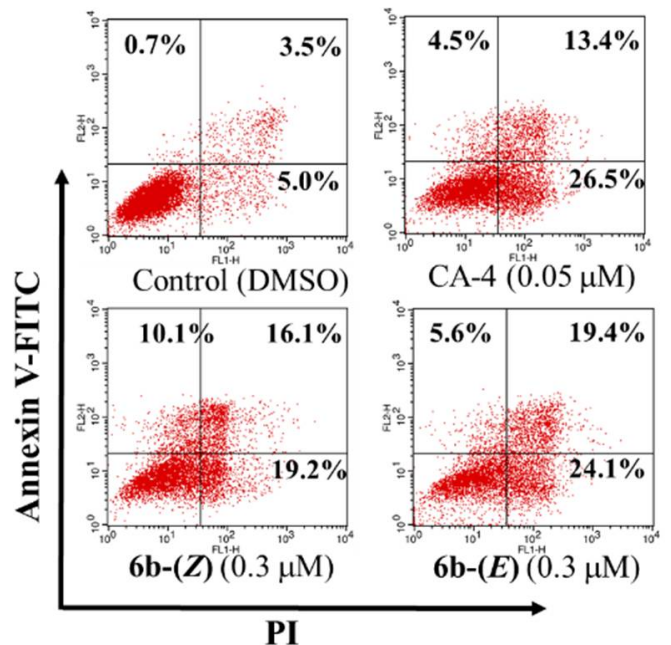

Figure 3. Induction of apoptosis by $\mathbf{6 b}-(\mathbf{Z}), \mathbf{6 b}-(E)$ and CA-4 at the indicated concentrations on HepG-2 cells. After treatment for $48 \mathrm{~h}$, the cells were stained with PI and Annexin V-FITC and viable, apoptotic and necrotic cells were analyzed by flow cytometry. Cells in lower left quadrants are alive, in the lower right quadrants are in early apoptosis, in the upper right quadrants are in late apoptosis and in the upper left quadrants are necrotic. Percentage of the total signal within the quadrant is indicated. Each experiment was performed in triplicate.

A striking character of anticancer activity of CA-4 and isoCA-4 is to induce cell cycle arrest at the G2/M phase [3,39]. To confirm whether the biological mechanism of these two isomers was caused by cell cycle accumulation at a G2/M phase, the cell cycle distribution of HepG2 cells was evaluated with PI staining by flow cytometry [40]. As shown in Figure 4, following treatment with $\mathbf{6 b - ( Z )}$ and $\mathbf{6 b}-(E)$ for $24 \mathrm{~h}$ at concentrations of $0.3 \mu \mathrm{M}$ and $1.0 \mu \mathrm{M}$, the percentages of cells in the G2/M phase at different concentrations were $18.5 \%$ and $89.8 \%$ for $6 \mathbf{b}-(Z)$ and $12.8 \%$ and $88.5 \%$ for $6 \mathbf{b}-(E)$, respectively, as compared to $12.2 \%$ in control cells, suggesting that these two isomers caused an obvious G2/M arrest with a similar mechanism to that of CA-4.
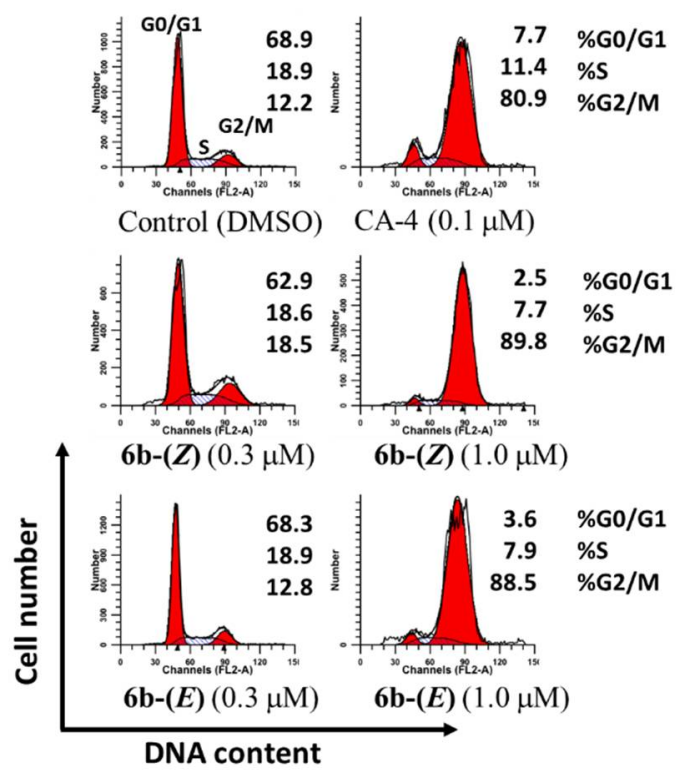

Figure 4. Analysis of cell cycle distribution in HepG-2 cells by flow cytometry. The cultured cells were treated with $\mathbf{6 b}-(\mathrm{Z}), \mathbf{6 b}-(E)$ and CA-4 at the indicated concentrations for $24 \mathrm{~h}$, then harvested, and analyzed using a FACS Calibur (BD Biosciences). 
To visualize the tubulin polymerization inhibition of these compounds in cells, immunofluorescence analysis was investigated on microtubule network in HepG2 cells. As shown in Figure 5, control cells displayed a normal distribution of microtubular network with a slim and fibrous shape. However, cells treated with CA-4 and $6 b-(E)$ showed a disrupted microtubule network (green) becoming short and wrapped around cell nucleus, demonstrating that $\mathbf{6 b}-(E)$ could inhibit the cellular tubulin polymerization.

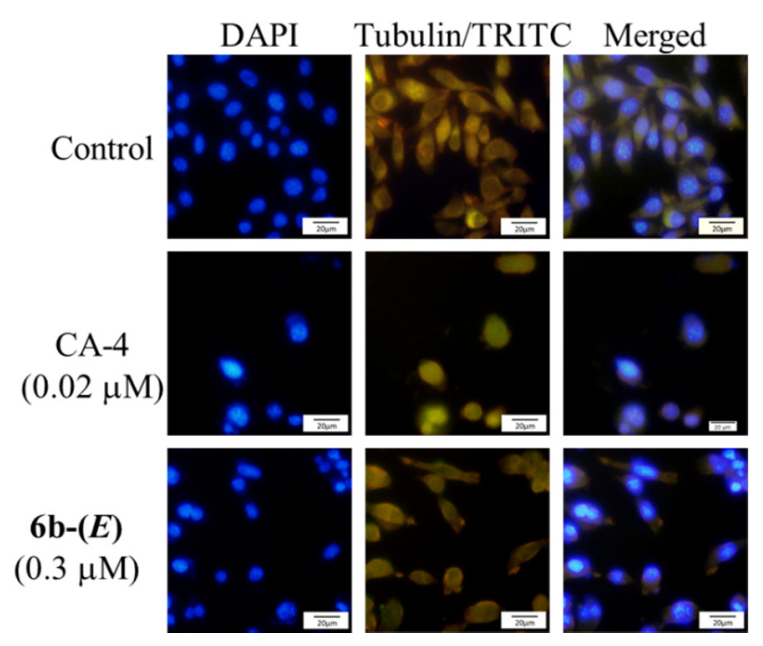

Figure 5. Immunofluorescence effects of $6 \mathrm{~b}-(E)(0.3 \mu \mathrm{M})$ and CA-4 $(0.02 \mu \mathrm{M})$ on inhibition of tubulin polymerization in HepG-2 cells. After treatment for $48 \mathrm{~h}$, the cells were stained with DAPI (blue, left panel) for nucleus and an anti- $\alpha$-tubulin antibody (TRITC, green, middle panel) for microtubules. The right panel represents a merge of the corresponding left and middle panels. Images were acquired with an Olympus fluorescence microscope using a $20 \times$ objective.

Furthermore, to investigate whether there is such an interaction of the active analogues with tubulin responsible for the activity, tubulin polymerization in vitro was measured for 50 min at $37^{\circ} \mathrm{C}$ with paclitaxel as a promoting-assembly control and CA-4 as a depolymerization control. As shown in Figure 6, paclitaxel promoted the assembly of tubulin, while CA-4 inhibited it well. Compound 6b-(E) displayed an inhibition effect for tubulin polymerization in a dose-dependent manner. From these results, it could be concluded that $6 \mathbf{b}-(E)$ could inhibit the assembly of tubulin, and the cellular activities of $6 b-(E)$ might be generated from this interaction with tubulin.

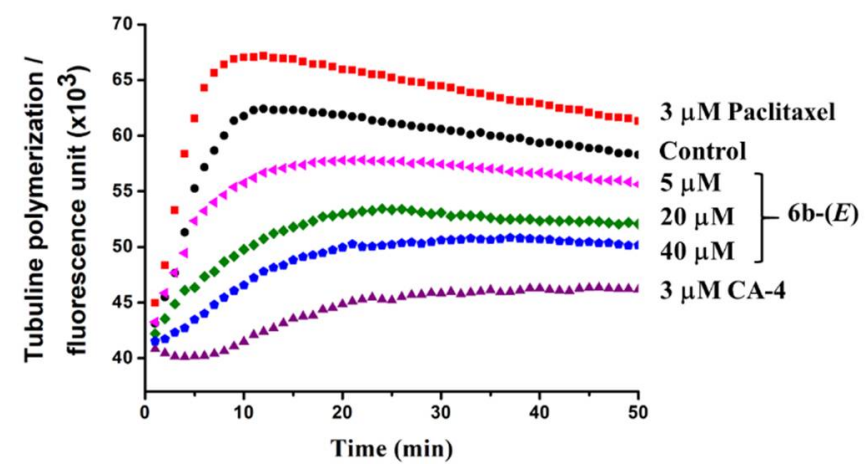

Figure 6. Effects of $\mathbf{6 b}-(\mathrm{E})$ on tubulin polymerization in vitro. Tubulin $(10 \mathrm{mg} / \mathrm{mL})$ was incubated with 6 -(E) $(5,20$ and $40 \mu \mathrm{M})$ for $50 \mathrm{~min}$ at $37^{\circ} \mathrm{C}$. Paclitaxel $(3 \mu \mathrm{M})$ and CA-4 $(3 \mu \mathrm{M})$ were used as positive controls. The fluorescence intensity was monitored every minute for characterization of tubulin polymerization at a $360 \mathrm{~nm}$ excitation wavelength and $460 \mathrm{~nm}$ emission wavelength. 


\subsection{Molecular Docking}

To elucidate the binding model of the analogues $6 \mathbf{b}-(Z)$ and $\mathbf{6 b}-(E)$ with the tubulin colchicine binding site, the X-ray crystal structure (PDB:1SA0) was employed for performing the docking studies using the Surflex-Dock program in the Sybyl-X 2.0 software. Figure 7a,b exhibits the docking studies of $\mathbf{6 b}-(Z)$ and $\mathbf{6 b}-(E)$ with the tubulin colchicine binding site of tubulin, respectively. Figure 7a shows that the meta-methoxy groups on alkene of $\mathbf{6 b}-(E)$ formed a hydrogen bond with the key amino acid Ser178 about $1.96 \AA$ bond distance, and the oxygen atoms of the hydroxyl groups on ring-B of $\mathbf{6 b}-(\mathbf{Z})$ formed a hydrogen bond with the key amino acid Cys241 about $2.35 \AA$. Figure $7 \mathrm{~b}$ exhibits that the meta-methoxy groups on ring-A of $\mathbf{6 b}-(E)$ formed a hydrogen bond with the key amino acid Cys241 about $1.93 \AA$, while the oxygen atoms of the hydroxyl groups on ring-B formed a hydrogen bond with the key amino acid Thr193 about $2.06 \AA$. From the simulated bond distance results, it can be concluded that $\mathbf{6 b}-(E)$ should have a better biological activity than $6 \mathrm{~b}-(\mathrm{Z})$, consisting with cytotoxicity test results. These docking studies suggested that the binding site of $6 \mathbf{b}-(Z)$ and $\mathbf{6 b}-(E)$ might be the tubulin colchicine binding site.

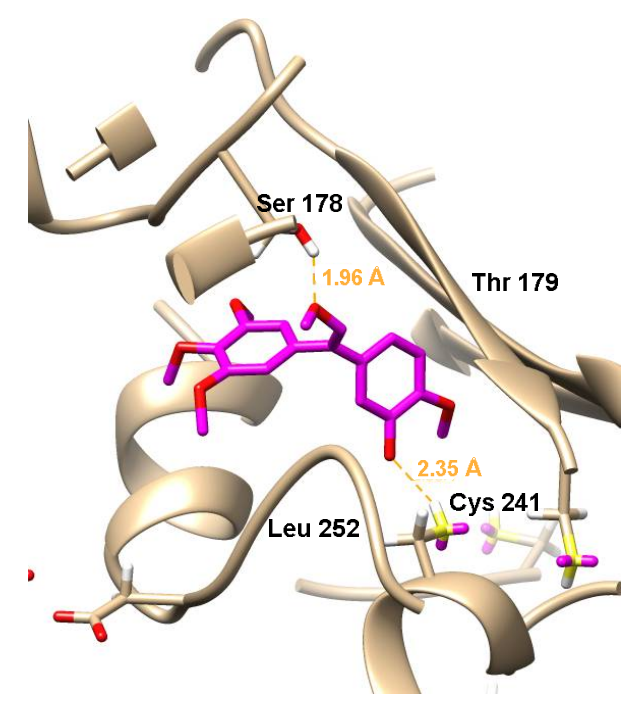

(a)

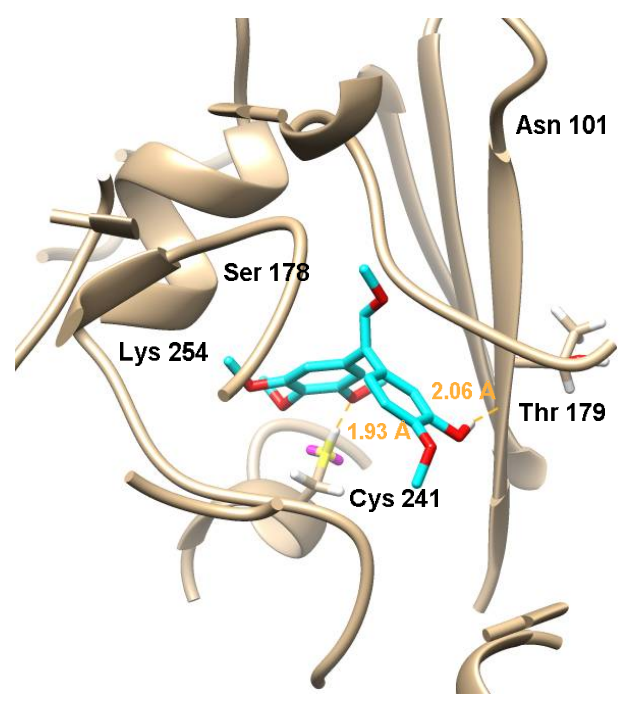

(b)

Figure 7. Molecular docking simulations obtained at lowest energy conformation, highlighting potential hydrogen contacts of (a) $\mathbf{6 b}-(Z)$ and (b) $6 \mathbf{b}-(E)$ with the colchicine's binding site of tubulin (PDB code: 1SA0). Surrounding key amino acid residues are labeled, and hydrogen bonds are shown by orange dashed lines.

\section{Materials and Methods}

\subsection{Chemistry}

\subsubsection{General}

All the compounds were recorded by a $500 \mathrm{MHz}$ Bruker NMR spectrometer (Bruker Daltonics Inc., Bremen, Germany) with ${ }^{1} \mathrm{H},{ }^{13} \mathrm{C}$ and DEPT135 $\mathrm{NMR}$ in $\mathrm{CDCl}_{3}$ solution with TMS as internal standard for protons. The 2D NOSEY experiment was carried out in the $500 \mathrm{MHz}$ Bruker NMR spectrometer with 32 of the scans number. Chemical shift values are mentioned in $\delta(\mathrm{ppm})$ and coupling constants $(J)$ in Hz. MS (ESI) was measured on an ESI-Thermo Fisher LTQ Fleet instrument spectrometer (Thermo Fisher Scientific Inc., Waltham, MA)The reaction progress was supervised by thin-layer chromatography (TLC), spots were observed under UV light (254 nm and $365 \mathrm{~nm}$ ) and colorized with 5\% phosphomolybdic acid. Silica gels (300-400 mesh, Qingdao Marine Chemical Ltd., 
Qingdao, China) were used for column chromatography. Waters 1525 series equipped with a PDA detector (Waters Corporation, Milford, MA) was used for analytical HPLC, and YMS-pack ODS-A column $(250 \mathrm{~mm} \times 10 \mathrm{~mm}, 5 \mu \mathrm{m})$ was used for semipreparation. All reagents were purchased from commercial sources, and purifications and desiccations of available solvents were accomplished by standard techniques prior to use. Positive control drug CA-4 was purchased from Sigma, and isoCA-4 was obtained refer to the previous report [37]. The purity of all compounds was confirmed to be greater than $95 \%$ through analytical HPLC.

\subsubsection{Synthesis of Diphenylethanone Analogue $\mathbf{5 a}, \mathbf{5 b}$ and by-Products $\mathbf{6} \mathbf{a}, \mathbf{6 b}$}

Preparation of compound 4 refers to our previous report method [37]. To a solution of 4 (11.2 g, $26 \mathrm{mmol}, 1 \mathrm{eq})$ in $\mathrm{MeOH}(85 \mathrm{~mL})$ was added $\mathrm{PhI}(\mathrm{OAc})_{2}(8.8 \mathrm{~g}, 27.3 \mathrm{mmol}, 1.05 \mathrm{eq})$ at $-20^{\circ} \mathrm{C}$. Then, $50 \%$ $\mathrm{H}_{2} \mathrm{SO}_{4}$ in $\mathrm{MeOH}(85 \mathrm{~mL})$ was added by drops. The mixture was stirred for $30 \mathrm{~min}$. The reaction was then quenched with saturated aqueous $\mathrm{NaHCO}_{3}$, and diluted by $\mathrm{H}_{2} \mathrm{O}(100 \mathrm{~mL})$. The resulting mixture was extracted with EtOAc $(3 \times 100 \mathrm{~mL})$. The combined organic layers were dried over anhydrous $\mathrm{Mg}_{2} \mathrm{SO}_{4}$, filtered and concentrated under reduced pressure. The residue was purified by flash column chromatography on silica gel with petroleum ether/EtOAc (15:1) to give $\mathbf{5 a}$ and $\mathbf{6 a}$.

$5 \mathbf{a}$ or $\mathbf{6 a}$ with the TBS protective group was dissolved in THF $(2 \mathrm{~mL})$, and treated with $1.0 \mathrm{M}$ TBAF (1.1 eq) in THF. The mixture was stirred for $0.5 \mathrm{~h}$ and diluted by $\mathrm{H}_{2} \mathrm{O}(10 \mathrm{~mL})$, and extracted with EtOAc $(3 \times 10 \mathrm{~mL})$. The combined organic layers were dried over anhydrous $\mathrm{Na}_{2} \mathrm{SO}_{4}$, filtered and concentrated under reduced pressure. The residue was purified by flash column chromatography on silica gel with petroleum ether/EtOAc (4:1) to give compounds $5 \mathbf{b}$ or $\mathbf{6} \mathbf{b}$, respectively. The mixture $\mathbf{6 a}$ was separated by preparative HPLC to afford $\mathbf{6 b}-(\mathbf{Z})$ and $\mathbf{6 b}-(E)$ with ratio of 1:1. $\mathbf{6 b}-(Z): t_{R}=18.6 \mathrm{~min}$, purity $=90.4 \% ; \mathbf{6 b}-(E): \mathrm{t}_{\mathrm{R}}=20.6 \mathrm{~min}$, purity $=91.8 \%$ at $220 \mathrm{~nm}, 30 \mathrm{~min}$ gradient, $40 \% \mathrm{MeOH}: 60 \% \mathrm{H}_{2} \mathrm{O}$ to $100 \% \mathrm{MeOH}$.

2-(3-((tert-butyldimethylsilyl)oxy)-4-methoxyphenyl)-1-(3,4-dimethoxyphenyl)ethan-1-one (5a): yellow viscosity liquid, $61 \%$ yield. ${ }^{1} \mathrm{H}$ NMR $\left(500 \mathrm{MHz}, \mathrm{CDCl}_{3}\right): \delta 7.28(\mathrm{~s}, 2 \mathrm{H}), 6.83(\mathrm{~s}, 2 \mathrm{H}), 6.79(\mathrm{~d}$, $J=1.0 \mathrm{~Hz}, 1 \mathrm{H}), 4.16(\mathrm{~s}, 2 \mathrm{H}), 3.93(\mathrm{~s}, 3 \mathrm{H}), 3.91(\mathrm{~s}, 6 \mathrm{H}), 3.81(\mathrm{~s}, 3 \mathrm{H}), 1.00(\mathrm{~s}, 9 \mathrm{H}), 0.15(\mathrm{~s}, 6 \mathrm{H}) ;{ }^{13} \mathrm{C} \mathrm{NMR}$ $\left(125 \mathrm{MHz}, \mathrm{CDCl}_{3}\right): \delta$ 196.77, $153.00(2 \mathrm{C}), 149.96,145.15,142.47,131.79,127.35,122.30,122.01,112.33$, $106.31(2 \mathrm{C}), 60.93,56.25(2 \mathrm{C}), 55.52,45.04,25.72(3 \mathrm{C}), 18.45,-4.62(2 \mathrm{C})$.

2-(3-hydroxy-4-methoxyphenyl)-1-(3,4,5-trimethoxyphenyl)ethan-1-one (5b): yellow solid, 95\% yield. ${ }^{1} \mathrm{H}$ NMR $\left(500 \mathrm{MHz}, \mathrm{CDCl}_{3}\right): \delta 7.24(\mathrm{~s}, 2 \mathrm{H}), 6.83(\mathrm{~d}, J=2.1 \mathrm{~Hz}, 1 \mathrm{H}), 6.76(\mathrm{~d}, J=8.3 \mathrm{~Hz}$, $1 \mathrm{H}), 6.71(\mathrm{dd}, J=8.3,2.1 \mathrm{~Hz}, 1 \mathrm{H}), 5.67(\mathrm{~s}, 1 \mathrm{H}), 4.50-4.46(\mathrm{~m}, 1 \mathrm{H}), 3.85(\mathrm{~s}, 3 \mathrm{H}), 3.84(\mathrm{~s}, 6 \mathrm{H}), 3.82(\mathrm{~s}, 3 \mathrm{H})$, $2.40-2.31(\mathrm{~m}, 5 \mathrm{H}), 2.08-2.02(\mathrm{~m}, 1 \mathrm{H}), 1.01(\mathrm{t}, J=7.3 \mathrm{~Hz}, 3 \mathrm{H}) ;{ }^{13} \mathrm{C} \mathrm{NMR}\left(126 \mathrm{MHz}, \mathrm{CDCl}_{3}\right): \delta 211.39$, $198.28,152.90(2 \mathrm{C}), 146.08,145.82,142.35,132.55,131.74,119.70,114.42,111.10,106.43(2 \mathrm{C}), 60.86,56.22$ (2C), 55.93, 51.66, 39.53, 35.96, 27.64, 7.86; MS (ESI): $m / z$ calcd for $\mathrm{C}_{18} \mathrm{H}_{21} \mathrm{O}_{6}{ }^{+}[\mathrm{M}+\mathrm{H}]+{ }^{+} 333.13$, found 333.34 .

(Z)-2-methoxy-5-(2-methoxy-1-(3,4,5-trimethoxyphenyl)vinyl)phenol (6b-(Z)): a yellow solid. ${ }^{1} \mathrm{H}$ NMR $\left(500 \mathrm{MHz}, \mathrm{CDCl}_{3}\right): \delta 6.76(\mathrm{~d}, J=2.1 \mathrm{~Hz}, 1 \mathrm{H}), 6.71(\mathrm{~d}, J=8.3 \mathrm{~Hz}, 1 \mathrm{H}), 6.64(\mathrm{~d}, J=2.1 \mathrm{~Hz}, 1 \mathrm{H}), 6.54$ $(\mathrm{s}, 2 \mathrm{H}), 6.32(\mathrm{~s}, 1 \mathrm{H}), 3.82(\mathrm{~s}, 3 \mathrm{H}), 3.79(\mathrm{~s}, 3 \mathrm{H}), 3.72(\mathrm{~s}, 6 \mathrm{H}), 3.68(\mathrm{~s}, 3 \mathrm{H}) ;{ }^{13} \mathrm{C} \mathrm{NMR}\left(126 \mathrm{MHz}, \mathrm{CDCl}_{3}\right)$ : $\delta 152.74(2 \mathrm{C}), 145.49,145.35,140.12,136.79,133.73,133.16,120.14,119.89,114.39,110.48,107.28(2 \mathrm{C})$, 60.85, 56.10 (2C), 56.02, 50.89; MS (ESI): $\mathrm{m} / z$ calcd for $\mathrm{C}_{19} \mathrm{H}_{23} \mathrm{O}_{6}{ }^{+}[\mathrm{M}+\mathrm{H}]^{+} 347.15$, found 347.05.

(E)-2-methoxy-5-(2-methoxy-1-(3,4,5-trimethoxyphenyl)vinyl)phenol (6b-(E)): a yellow solid. ${ }^{1} \mathrm{H}$ NMR $\left(500 \mathrm{MHz}, \mathrm{CDCl}_{3}\right): \delta 7.06(\mathrm{~d}, J=2.1 \mathrm{~Hz}, 1 \mathrm{H}), 6.90-6.86(\mathrm{~m}, 1 \mathrm{H}), 6.81(\mathrm{~d}, J=8.4 \mathrm{~Hz}, 1 \mathrm{H}), 6.43(\mathrm{~s}$, $2 \mathrm{H}), 6.35(\mathrm{~s}, 1 \mathrm{H}), 3.89(\mathrm{~s}, 3 \mathrm{H}), 3.85(\mathrm{~s}, 3 \mathrm{H}), 3.81(\mathrm{~s}, 6 \mathrm{H}), 3.76(\mathrm{~s}, 3 \mathrm{H})$; MS (ESI): $\mathrm{m} / \mathrm{z}$ calcd for $\mathrm{C}_{19} \mathrm{H}_{23} \mathrm{O}_{6}{ }^{+}$ $[\mathrm{M}+\mathrm{H}]+347.15$, found 347.06 . 
3.1.3. Synthesis of Cis-Locked Dihydrofuran Analogues 7a, $7 \mathbf{b}$ and $\alpha$-Substituted Diphenylethanones $8 \mathrm{a}, 8 \mathrm{~b}$

To a solution of compound $5 \mathrm{a}(1.0 \mathrm{eq})$ and $\mathrm{Cu}(\mathrm{OAc})_{2}$ (3.0 eq) in DCE was added olefin (3.0 eq), then the mixture was heated to $110{ }^{\circ} \mathrm{C}$, and stirred for $4 \mathrm{~h}$. The reaction was filtered by diatomite, and diluted by $\mathrm{H}_{2} \mathrm{O}$. The resulting mixture was extracted with EtOAc. The combined organic layers were dried over anhydrous $\mathrm{Na}_{2} \mathrm{SO}_{4}$, filtered and concentrated under reduced pressure. The residue was purified by flash column chromatography on silica gel with petroleum ether/EtOAc to give target compounds with the TBS protective group. Next, compound with TBS group was dissolved in THF $(2 \mathrm{~mL})$, and treated with 1.0 M TBAF (1.1 eq) in THF. The mixture was stirred for $0.5 \mathrm{~h}$. The reaction was diluted by $\mathrm{H}_{2} \mathrm{O}(10 \mathrm{~mL})$, and extracted with EtOAc $(3 \times 10 \mathrm{~mL})$. The combined organic layers were dried over anhydrous $\mathrm{Na}_{2} \mathrm{SO}_{4}$, filtered, and concentrated under reduced pressure. The residue was purified by flash column chromatography on silica gel with petroleum ether/EtOAc (4:1) to give 7a and $7 \mathbf{b}$.

2-methoxy-5-(5-phenyl-2-(3,4,5-trimethoxyphenyl)-4,5-dihydrofuran-3-yl)phenol (7a): yellow solid. Two steps yield: $65 \% .{ }^{1} \mathrm{H}$ NMR $\left(500 \mathrm{MHz}, \mathrm{CDCl}_{3}\right): \delta 7.48(\mathrm{~d}, J=7.7 \mathrm{~Hz}, 2 \mathrm{H}), 7.39(\mathrm{t}, J=7.5 \mathrm{~Hz}, 2 \mathrm{H})$, $7.32(\mathrm{t}, J=7.0 \mathrm{~Hz}, 1 \mathrm{H}), 6.90(\mathrm{~s}, 1 \mathrm{H}), 6.83(\mathrm{~s}, 2 \mathrm{H}), 6.76(\mathrm{q}, J=8.4 \mathrm{~Hz}, 2 \mathrm{H}), 5.67(\mathrm{t}, J=9.5 \mathrm{~Hz}, 1 \mathrm{H}), 5.54(\mathrm{~s}$, $1 \mathrm{H}), 3.86(\mathrm{~s}, 3 \mathrm{H}), 3.86(\mathrm{~s}, 3 \mathrm{H}), 3.72(\mathrm{~s}, 6 \mathrm{H}), 3.54(\mathrm{dd}, J=15.0,10.4 \mathrm{~Hz}, 1 \mathrm{H}), 3.17(\mathrm{dd}, J=15.0,8.6 \mathrm{~Hz}, 1 \mathrm{H})$; ${ }^{13} \mathrm{C}$ NMR $\left(125 \mathrm{MHz}, \mathrm{CDCl}_{3}\right): \delta 152.89$ (2C), 148.74, 145.44, 145.13, 143.02, 128.62 (2C), 127.78, 126.91, 125.79 (2C), 119.65, 114.01, 110.58, 108.88, 105.40 (2C), 80.42, 60.91, 56.04 (3C), 44.85; MS (ESI): $\mathrm{m} / z$ calcd for $\mathrm{NaC}_{26} \mathrm{H}_{26} \mathrm{O}_{6}[\mathrm{M}+\mathrm{Na}]^{+}$457.16, found 457.49 .

2-methoxy-5-(5-methyl-2-(3,4,5-trimethoxyphenyl)-5-vinyl-4,5-dihydrofuran-3-yl)phenol (7b): yellow solid. Two steps yield: $45 \% .{ }^{1} \mathrm{H}$ NMR $\left(500 \mathrm{MHz}, \mathrm{CDCl}_{3}\right): \delta 6.85(\mathrm{~s}, 1 \mathrm{H}), 6.76(\mathrm{~s}, 2 \mathrm{H}), 6.73(\mathrm{~s}$, $2 \mathrm{H}), 6.11(\mathrm{dd}, J=17.3,10.7 \mathrm{~Hz}, 1 \mathrm{H}), 5.52(\mathrm{~s}, 1 \mathrm{H}), 5.34(\mathrm{dd}, J=17.3,1.1 \mathrm{~Hz}, 1 \mathrm{H}), 5.12(\mathrm{dd}, J=10.7,1.1 \mathrm{~Hz}$, $1 \mathrm{H}), 3.86(\mathrm{~s}, 3 \mathrm{H}), 3.84(\mathrm{~s}, 3 \mathrm{H}), 3.72(\mathrm{~s}, 6 \mathrm{H}), 3.09(\mathrm{~d}, J=14.9 \mathrm{~Hz}, 1 \mathrm{H}), 2.98(\mathrm{~d}, J=14.9 \mathrm{~Hz}, 1 \mathrm{H}), 1.58(\mathrm{~s}, 3 \mathrm{H})$; ${ }^{13} \mathrm{C}$ NMR (125 MHz, $\left.\mathrm{CDCl}_{3}\right): \delta 152.87$ (2C), 147.82, 145.36, 144.94, 142.49, 138.31, 129.50, 127.40, 119.46, 113.83, 112.23, 110.53, 108.37, 105.36 (2C), 83.41, 60.90, 56.04, 56.03 (2C), 48.00, 26.27; MS (ESI): $\mathrm{m} / \mathrm{z}$ calcd for $\mathrm{NaC}_{23} \mathrm{H}_{26} \mathrm{O}_{6}[\mathrm{M}+\mathrm{Na}]^{+} 421.16$, found 421.67 .

2-(3-((tert-butyldimethylsilyl)oxy)-4-methoxyphenyl)-1-(3,4,5-trimethoxyphenyl)heptane-1,5-dione (8a): yellow viscosity liquid, 36\% yield. ${ }^{1} \mathrm{H}$ NMR $\left(500 \mathrm{MHz}, \mathrm{CDCl}_{3}\right): \delta 7.22(\mathrm{~s}, 2 \mathrm{H}), 6.77(\mathrm{~s}, 2 \mathrm{H}), 6.71(\mathrm{~s}$, $1 \mathrm{H}), 4.46(\mathrm{~s}, 1 \mathrm{H}), 3.85(\mathrm{~s}, 3 \mathrm{H}), 3.84(\mathrm{~s}, 6 \mathrm{H}), 3.75(\mathrm{~s}, 3 \mathrm{H}), 2.40-2.32(\mathrm{~m}, 5 \mathrm{H}), 2.04(\mathrm{~d}, J=7.2 \mathrm{~Hz}, 1 \mathrm{H}), 1.02(\mathrm{~s}$, 3H), 0.95 (s, 9H), 0.09 (s, 6H); ${ }^{13} \mathrm{C}$ NMR $\left(125 \mathrm{MHz}, \mathrm{CDCl}_{3}\right): \delta 211.40,198.48,152.89(2 \mathrm{C}), 150.14,145.39$, $142.28,131.90,131.87,121.33,120.91,112.47,106.41$ (2C), 60.87, 56.21 (2C), 55.46, 51.56, 39.50, 35.96, 27.61, 25.69 (3C), 18.44, 7.87, $-4.460,-4.61$; MS (ESI): $\mathrm{m} / z$ calcd for $\mathrm{SiC}_{29} \mathrm{H}_{43} \mathrm{O}_{7}[\mathrm{M}+\mathrm{H}]^{+} 531.28$, found 531.62.

2-(3-hydroxy-4-methoxyphenyl)-1-(3,4,5-trimethoxyphenyl)heptane-1,5-dione (8b): white solid, 95\% yield. ${ }^{1} \mathrm{H}$ NMR $\left(500 \mathrm{MHz}, \mathrm{CDCl}_{3}\right): \delta 7.24(\mathrm{~s}, 2 \mathrm{H}), 6.83(\mathrm{~d}, J=2.1 \mathrm{~Hz}, 1 \mathrm{H}), 6.76(\mathrm{~d}, J=8.3 \mathrm{~Hz}, 1 \mathrm{H}), 6.71$ $(\mathrm{dd}, J=8.3,2.1 \mathrm{~Hz}, 1 \mathrm{H}), 5.67(\mathrm{~s}, 1 \mathrm{H}), 4.50-4.46(\mathrm{~m}, 1 \mathrm{H}), 3.85(\mathrm{~s}, 3 \mathrm{H}), 3.84(\mathrm{~s}, 6 \mathrm{H}), 3.82(\mathrm{~s}, 3 \mathrm{H}), 2.40-2.31$ $(\mathrm{m}, 5 \mathrm{H}), 2.08-2.02(\mathrm{~m}, 1 \mathrm{H}), 1.01(\mathrm{t}, J=7.3 \mathrm{~Hz}, 3 \mathrm{H}) ;{ }^{13} \mathrm{C} \mathrm{NMR}\left(125 \mathrm{MHz}, \mathrm{CDCl}_{3}\right): \delta 211.39,198.28,152.90$ (2C), 146.08, 145.82, 142.35, 132.55, 131.74, 119.70, 114.42, 111.10, 106.43 (2C), 60.86, 56.22 (2C), 55.93, 51.66, 39.53, 35.96, 27.64, 7.86; MS (ESI): $\mathrm{m} / z$ calcd for $\mathrm{NaC}_{23} \mathrm{H}_{28} \mathrm{O}_{7}[\mathrm{M}+\mathrm{Na}]^{+} 439.17$, found 439.46 .

\subsubsection{Synthesis of Cyclobutane Analogue 9}

To a solution of $8 \mathbf{a}(0.5 \mathrm{mmol}, 1.0 \mathrm{eq})$ in dry THF $(10 \mathrm{~mL})$ was added $1 \mathrm{M}$ LiHMDS solution in THF $(1.0 \mathrm{~mL}, 1.0 \mathrm{mmol}, 2.0 \mathrm{eq})$ at $-78{ }^{\circ} \mathrm{C}$ under argon atmosphere. After stirred for $1 \mathrm{~h}$, the reaction was added $p$-toluensulfonyl chloride ( $\mathrm{TsCl}, 191 \mathrm{mg}, 1.88 \mathrm{mmol}, 2.0 \mathrm{eq})$ solution in THF $(2 \mathrm{~mL})$. The reaction stirred overnight, and quenched with saturated aqueous $\mathrm{NH}_{4} \mathrm{Cl}$, diluted by $\mathrm{H}_{2} \mathrm{O}(10 \mathrm{~mL})$. The resulting mixture was extracted with EtOAc $(3 \times 10 \mathrm{~mL})$. The combined organic layers were 
dried over anhydrous $\mathrm{Mg}_{2} \mathrm{SO}_{4}$, filtered, and concentrated under reduced pressure. The flash column chromatography on silica gel with petroleum ether/EtOAc (8:1) gave 9.

1-(3-(3-((tert-butyldimethylsilyl)oxy)-4-methoxyphenyl)-2-hydroxy-2-(3,4,5-trimethoxyphenyl) cyclobutyl)propan-1-one (9): yellow solid, 40\% yield. ${ }^{1} \mathrm{H} \mathrm{NMR}\left(500 \mathrm{MHz}, \mathrm{CDCl}_{3}\right): \delta 6.70(\mathrm{~d}$, $J=0.8 \mathrm{~Hz}, 2 \mathrm{H}), 6.63(\mathrm{~s}, 1 \mathrm{H}), 6.45(\mathrm{~s}, 2 \mathrm{H}), 3.80(\mathrm{~s}, 3 \mathrm{H}), 3.78(\mathrm{~s}, 6 \mathrm{H}), 3.73(\mathrm{~s}, 3 \mathrm{H}), 3.69(\mathrm{~d}, J=3.4 \mathrm{~Hz}, 1 \mathrm{H})$, $3.50(\mathrm{dd}, J=12.1,3.3 \mathrm{~Hz}, 1 \mathrm{H}), 2.72-2.52(\mathrm{~m}, 4 \mathrm{H}), 2.10(\mathrm{~s}, 1 \mathrm{H}), 0.92(\mathrm{~s}, 12 \mathrm{H}), 0.03(\mathrm{~s}, 6 \mathrm{H}) ;{ }^{13} \mathrm{C} \mathrm{NMR}$ $\left(126 \mathrm{MHz}, \mathrm{CDCl}_{3}\right): \delta 213.47,152.69$ (2C), 150.01, 144.79, 139.75, 136.98, 132.28, 122.09, 122.02, 111.97, 103.82 (2C), 80.85, 0.81, 56.89, 56.17 (2C), 55.42, 47.27, 38.30, 27.28, 25.66 (3C), 18.36, 12.99, -4.66, -4.72; MS (ESI): $m / z$ calcd for $\mathrm{SiC}_{29} \mathrm{H}_{43} \mathrm{O}_{7}[\mathrm{M}+\mathrm{H}]^{+} 531.28$, found 531.74 .

\subsubsection{Synthesis of Cyclohexane Analogue 10a, 10b and 11, 12}

To a solution of $8 \mathrm{a}(1.87 \mathrm{~g}, 35.2 \mathrm{mmol}, 1.0 \mathrm{eq})$ in $\mathrm{MeOH}(10 \mathrm{~mL})$ was added $\mathrm{LiOH}(844 \mathrm{mg}$, $35.2 \mathrm{mmol}, 1.0 \mathrm{eq}$ ) at $0{ }^{\circ} \mathrm{C}$. After stirring for $0.5 \mathrm{~h}$, the solution was quenched with saturated aqueous $\mathrm{NH}_{4} \mathrm{Cl}$, diluted by $\mathrm{H}_{2} \mathrm{O}(20 \mathrm{~mL})$. The resulting mixture was extracted with EtOAc $(3 \times 20 \mathrm{~mL})$. The combined organic layers were dried over anhydrous $\mathrm{Na}_{2} \mathrm{SO}_{4}$, filtered, and concentrated under reduced pressure. The residue was purified by flash column chromatography on silica gel with petroleum ether/EtOAc (10: 1) to give $560 \mathrm{mg}$ compounds 10a.

To a solution of 10a ( $20 \mathrm{mg}, 0.38 \mathrm{mmol}, 1.0 \mathrm{eq})$ in THF $(2 \mathrm{~mL})$ was added $1.0 \mathrm{M}$ TBAF $(42 \mu \mathrm{L}$, $0.42 \mathrm{mmol}, 1.1 \mathrm{eq})$ in THF. The mixture was stirred for $0.5 \mathrm{~h}$. The reaction was diluted by $\mathrm{H}_{2} \mathrm{O}(10 \mathrm{~mL})$, and extracted with EtOAc $(3 \times 10 \mathrm{~mL})$. The combined organic layers were dried over anhydrous $\mathrm{Na}_{2} \mathrm{SO}_{4}$, filtered and concentrated under reduced pressure. The residue was purified by flash column chromatography on silica gel with petroleum ether/EtOAc (4:1) to give $15 \mathrm{mg}$ compounds $\mathbf{1 0 b}$.

To a solution of 10a (30 mg, $56 \mu \mathrm{mol}, 1.0 \mathrm{eq})$ in dry DCM $(5 \mathrm{~mL})$ was added $\mathrm{NaBH}_{4}(7.6 \mathrm{mg}$, $113 \mu \mathrm{mol}, 2.0 \mathrm{eq})$ at $0{ }^{\circ} \mathrm{C}$. After stirred for $2 \mathrm{~h}$, the reaction was then quenched with saturated aqueous $\mathrm{NH}_{4} \mathrm{Cl}$, and diluted by $\mathrm{H}_{2} \mathrm{O}(5 \mathrm{~mL})$. The resulting mixture was extracted with EtOAc $(5 \times 10 \mathrm{~mL})$. The combined organic layers were dried over anhydrous $\mathrm{Mg}_{2} \mathrm{SO}_{4}$, filtered and concentrated under reduced pressure. The residue was redissolved in THF $(3 \mathrm{~mL})$, and treated with $1.0 \mathrm{M}$ TBAF $(62 \mu \mathrm{L}$, $62 \mu \mathrm{mol}, 1.1 \mathrm{eq})$ in THF. The mixture was stirred for $0.5 \mathrm{~h}$. The reaction was diluted by $\mathrm{H}_{2} \mathrm{O}(5 \mathrm{~mL})$, and extracted with EtOAc $(3 \times 5 \mathrm{~mL})$. The combined organic layers were dried over anhydrous $\mathrm{Na}_{2} \mathrm{SO}_{4}$, filtered and concentrated under reduced pressure. The residue was purified by flash column chromatography on silica gel with petroleum ether/EtOAc (2: 1) to give $10 \mathrm{mg}$ compounds 11.

To a solution of 10a (500 mg, $0.94 \mathrm{mmol}, 1.0 \mathrm{eq})$ in dry THF $(10 \mathrm{~mL})$ was added $1 \mathrm{M}$ LiHMDS solution in THF $(1.88 \mathrm{~mL}, 1.88 \mathrm{mmol}, 2.0 \mathrm{eq})$ at $-78{ }^{\circ} \mathrm{C}$ under argon atmosphere. After being stirred for $1 \mathrm{~h}$, the reaction was added to $\mathrm{TsCl}(360 \mathrm{mg}, 1.88 \mathrm{mmol}, 2.0 \mathrm{eq})$ solution in THF $(3 \mathrm{~mL})$. The reaction stirred overnight, and quenched with saturated aqueous $\mathrm{NH}_{4} \mathrm{Cl}$, diluted by $\mathrm{H}_{2} \mathrm{O}(10 \mathrm{~mL})$. The resulting mixture was extracted with EtOAc $(3 \times 10 \mathrm{~mL})$. The combined organic layers were dried over anhydrous $\mathrm{Mg}_{2} \mathrm{SO}_{4}$, filtered and concentrated under reduced pressure. The residue was redissolved in DMF $(3 \mathrm{~mL})$, and added DMAP (12 mg, $94 \mu \mathrm{mol}, 0.1 \mathrm{eq})$ and $\mathrm{Et}_{3} \mathrm{~N}(1.3 \mathrm{~mL}, 9.4 \mathrm{mmol}, 10 \mathrm{eq})$. The reaction was heated to $80^{\circ} \mathrm{C}$, and stirred overnight, then quenched with saturated aqueous $\mathrm{NH}_{4} \mathrm{Cl}$, diluted by $\mathrm{H}_{2} \mathrm{O}$ $(30 \mathrm{~mL})$. The resulting mixture was extracted with EtOAc $(3 \times 20 \mathrm{~mL})$. The combined organic layers were dried over anhydrous $\mathrm{Na}_{2} \mathrm{SO}_{4}$, filtered and concentrated under reduced pressure. The residue was redissolved in THF $(5 \mathrm{~mL})$, and treated with $1.0 \mathrm{M}$ TBAF $(940 \mu \mathrm{L}, 0.94 \mathrm{mmol}, 1.0 \mathrm{eq})$ in THF. The mixture was stirred for $0.5 \mathrm{~h}$. The reaction was diluted by $\mathrm{H}_{2} \mathrm{O}(10 \mathrm{~mL})$, and extracted with EtOAc $(3 \times 10 \mathrm{~mL})$. The combined organic layers were dried over anhydrous $\mathrm{Na}_{2} \mathrm{SO}_{4}$, filtered, and concentrated under reduced pressure. The residue was purified by flash column chromatography on silica gel with petroleum ether/EtOAc (4:1) to give $93 \mathrm{mg}$ compounds $\mathbf{1 2}$ as a white solid.

4-(3-((tert-butyldimethylsilyl)oxy)-4-methoxyphenyl)-3-hydroxy-2-methyl-3-(3,4,5-trimethoxyphenyl) cyclohexan-1-one (10a): white solid, $65 \%$ yield. ${ }^{1} \mathrm{H}$ NMR $\left(500 \mathrm{MHz}, \mathrm{CDCl}_{3}\right): \delta 6.56(\mathrm{~d}, J=7.9 \mathrm{~Hz}$, $1 \mathrm{H}), 6.48(\mathrm{~d}, J=8.3 \mathrm{~Hz}, 2 \mathrm{H}), 3.77(\mathrm{~s}, 3 \mathrm{H}), 3.68(\mathrm{~s}, 3 \mathrm{H}), 3.35(\mathrm{~d}, J=11.2 \mathrm{~Hz}, 1 \mathrm{H}), 3.08(\mathrm{~d}, J=6.5 \mathrm{~Hz}, 1 \mathrm{H})$, 
$2.72-2.52(\mathrm{~m}, 3 \mathrm{H}), 2.09(\mathrm{~d}, J=11.8 \mathrm{~Hz}, 1 \mathrm{H}), 1.97(\mathrm{~s}, 1 \mathrm{H}), 0.92(\mathrm{~s}, 9 \mathrm{H}), 0.80(\mathrm{~d}, J=6.3 \mathrm{~Hz}, 3 \mathrm{H}), 0.02(\mathrm{~s}$, $3 \mathrm{H}),-0.02(\mathrm{~s}, 3 \mathrm{H}) ;{ }^{13} \mathrm{C}$ NMR $\left(125 \mathrm{MHz}, \mathrm{CDCl}_{3}\right): \delta 210.40,149.77,144.33,140.22,136.61,132.41,121.77$, 121.76, 111.50, 82.95, 60.84, 56.18, 56.16, 55.48, 53.62, 52.88, 41.56, 28.97, 25.67 (3C), 18.36, 8.15, -4.75, -4.84; MS (ESI): $\mathrm{m} / z$ calcd for $\mathrm{SiC}_{29} \mathrm{H}_{43} \mathrm{O}_{7}[\mathrm{M}+\mathrm{H}]^{+} 531.28$, found 531.63 .

3-hydroxy-4-(3-hydroxy-4-methoxyphenyl)-2-methyl-3-(3,4,5-trimethoxyphenyl)cyclohexan-1-one (10b): white solid, 95\% yield. ${ }^{1} \mathrm{H}$ NMR (500 MHz, DMSO-D6): $\delta 8.49(\mathrm{~s}, 1 \mathrm{H}), 6.57(\mathrm{~d}, J=1.5 \mathrm{~Hz}, 1 \mathrm{H})$, $6.55(\mathrm{~d}, J=8.3 \mathrm{~Hz}, 1 \mathrm{H}), 6.35(\mathrm{~d}, J=8.2 \mathrm{~Hz}, 1 \mathrm{H}), 4.94(\mathrm{~s}, 1 \mathrm{H}), 3.62(\mathrm{~s}, 3 \mathrm{H}), 3.56(\mathrm{~s}, 3 \mathrm{H}), 3.39(\mathrm{dd}, J=12.6$, $3.3 \mathrm{~Hz}, 1 \mathrm{H}), 3.34-3.31(\mathrm{~m}, 1 \mathrm{H}), 2.71(\mathrm{td}, J=13.3,6.6 \mathrm{~Hz}, 1 \mathrm{H}), 2.46-2.31(\mathrm{~m}, 2 \mathrm{H}), 1.90-1.83(\mathrm{~m}, 1 \mathrm{H})$, $0.66 \mathrm{ppm}(\mathrm{d}, J=6.7 \mathrm{~Hz}, 3 \mathrm{H}) ;{ }^{13} \mathrm{C}$ NMR $(125 \mathrm{MHz}$, DMSO-D6 $): \delta 211.12,146.07,145.68,141.49,135.85$, $135.35,120.18,116.97,111.59,82.75,60.42,55.96,53.75,52.64,41.40,29.85,8.79$; MS (ESI): $m / z$ calcd for $\mathrm{NaC}_{23} \mathrm{H}_{28} \mathrm{O}_{7}[\mathrm{M}+\mathrm{Na}]^{+}$439.17, found 439.59 .

6-(3-hydroxy-4-methoxyphenyl)-2-methyl-1-(3,4,5-trimethoxyphenyl)cyclohexane-1,3-diol (11): white solid, two steps yield: $66 \% .{ }^{1} \mathrm{H}$ NMR $\left(500 \mathrm{MHz}, \mathrm{CDCl}_{3}\right): \delta 7.66(\mathrm{dd}, J=259.2,6.5 \mathrm{~Hz}, 1 \mathrm{H}), 6.52$ $(\mathrm{s}, 1 \mathrm{H}), 6.50(\mathrm{~s}, 2 \mathrm{H}), 6.20(\mathrm{~d}, J=6.9 \mathrm{~Hz}, 1 \mathrm{H}), 6.11(\mathrm{~s}, 1 \mathrm{H}), 5.48(\mathrm{~s}, 1 \mathrm{H}), 3.90(\mathrm{~s}, 3 \mathrm{H}), 3.84(\mathrm{~d}, J=10.0 \mathrm{~Hz}$, $1 \mathrm{H}), 3.79(\mathrm{~s}, 3 \mathrm{H}), 3.76(\mathrm{~s}, 3 \mathrm{H}), 3.54(\mathrm{~s}, 3 \mathrm{H}), 2.86(\mathrm{~d}, J=12.1 \mathrm{~Hz}, 1 \mathrm{H}), 2.48(\mathrm{~s}, 1 \mathrm{H}), 2.24(\mathrm{dd}, J=27.5,12.3$ $\mathrm{Hz}, 2 \mathrm{H}), 1.98(\mathrm{~s}, 1 \mathrm{H}), 1.63(\mathrm{dd}, J=23.6,11.6 \mathrm{~Hz}, 2 \mathrm{H}), 0.86(\mathrm{~s}, 3 \mathrm{H}) ;{ }^{13} \mathrm{C} \mathrm{NMR}\left(125 \mathrm{MHz}, \mathrm{CDCl}_{3}\right): \delta 145.10$, 144.96, 141.62, 136.48, 134.03, 130.25, 127.08, 120.49, 114.73, 110.00, 103.80, 101.65, 79.72, 72.37, 60.92, $56.38,56.09,55.86,53.40,48.04,35.44,26.56,11.48$; MS (ESI): $\mathrm{m} / z$ calcd for $\mathrm{NaC}_{23} \mathrm{H}_{30} \mathrm{O}_{7}[\mathrm{M}+\mathrm{Na}]^{+} 441.19$, found 441.68 .

5-(3-hydroxy-4-methoxyphenyl)-1-methyl-6-(3,4,5-trimethoxyphenyl)-7-oxabicyclo[4.1.0]heptan-2one (12): white solid, three steps yield: $28 \% .{ }^{1} \mathrm{H}$ NMR $\left(500 \mathrm{MHz}, \mathrm{CDCl}_{3}\right): \delta 6.80(\mathrm{~s}, 1 \mathrm{H}), 6.60(\mathrm{t}$, $J=5.6 \mathrm{~Hz}, 2 \mathrm{H}), 6.32(\mathrm{~s}, 2 \mathrm{H}), 5.48(\mathrm{~s}, 1 \mathrm{H}), 3.79(\mathrm{~s}, 3 \mathrm{H}), 3.76(\mathrm{~s}, 3 \mathrm{H}), 3.43(\mathrm{~d}, J=10.9 \mathrm{~Hz}, 1 \mathrm{H}), 2.73(\mathrm{~d}$, $J=15.3 \mathrm{~Hz}, 1 \mathrm{H}), 2.44-2.29(\mathrm{~m}, 2 \mathrm{H}), 1.91-1.84(\mathrm{~m}, 1 \mathrm{H}), 1.13(\mathrm{~s}, 3 \mathrm{H}) ;{ }^{13} \mathrm{C} \mathrm{NMR}\left(125 \mathrm{MHz}, \mathrm{CDCl}_{3}\right): \delta$ 205.58, 152.78 (2C), 145.34, 145.26, 137.09,134.93, 132.67, 119.84, 114.35, 110.31, 72.21, 65.16, 60.82, 56.19, $55.84(2 \mathrm{C}), 45.67,37.13,26.33,13.05$; $\mathrm{MS}$ (ESI): $\mathrm{m} / \mathrm{z}$ calcd for $\mathrm{NaC}_{23} \mathrm{H}_{26} \mathrm{O}_{7}[\mathrm{M}+\mathrm{Na}]^{+} 437.16$, found 437.34 .

\subsection{Biological Activity Evaluation}

\subsubsection{Cell Culture}

The HepG2 cell line was originally acquired from Shanghai Institute of Biochemistry and Cell Biology, Chinese Academy of Sciences. This cell line was grown in RPMI-1640 (Gibco) including 10\% $(\mathrm{v} / \mathrm{v})$ thermally inactivated fetal bovine serum (FBS), penicillin $(100 \mathrm{KU} / \mathrm{L})$ and streptomycin $(100 \mathrm{KU} / \mathrm{L})$ at $37^{\circ} \mathrm{C}$ in a $5 \% \mathrm{CO}_{2}$ humidified incubator.

\subsubsection{Cytotoxic Activity (SRB Assay)}

In vitro cytotoxic activity was evaluated by using the SRB colorimetric assay as previous methods [38,41]. HepG2 cells were treated with analogues for $48 \mathrm{~h}$ at various concentrations.

\subsubsection{Apoptosis-Inducing Activity (PI/Annexin V-FITC Assay)}

The apoptosis in HepG2 cells was detected with a propidium iodide (PI)/Annexin V-FITC apoptosis detection kit (KeyGEN Biotech, Nanjing, China) as described previously [42]. After the treatment of 6b-(Z), $\mathbf{6 b}-(E)$ and CA-4 at the indicated concentrations for 48 h, HepG-2 cells were stained with PI and Annexin V-FITC and then were resuspended in $400 \mu \mathrm{L}$ of binding buffer. Flow cytometric analysis (FACS Calibur; Becton-Dickinson, San Jose, CA, US) was performed. A total of 10000 cells were acquired per sample and data were analyzed using Cellquest software (Becton-Dickinson, San Jose, CA, US). 


\subsubsection{Cell Cycle Distribution (PI Staining Assay)}

Cell cycle distribution on HepG2 cells was assessed by flow cytometry. PI staining assay (Sigma) was used for the cell cycle arrest of cells as described previously [40]. After treatment with test compound 1 at the indicated concentrations for $24 \mathrm{~h}$, cells were centrifuged and fixed in $70 \%$ ethanol at $4{ }^{\circ} \mathrm{C}$ overnight and subsequently resuspended in PBS containing $100 \mu \mathrm{L}$ RNase A and $400 \mu \mathrm{L}$ PI. Cellular DNA content, for cell cycle distribution analysis, was measured using a FACS Calibur flow cytometer (Becton-Dickinson, San Jose, CA, US) and analyzed using a CellQuest software package (Becton-Dickinson, San Jose, CA, US). Twenty thousand events were collected per sample. Mean values from 3 independent experiments are presented. The results were analyzed using Modfit LT 3.0 software.

\subsubsection{Immunofluorescence Analysis (DAPI/ $\alpha$-Tubulin-TRITC Assay)}

Immunofluorescence effects of $\mathbf{6 b}-(E)$ and CA-4 on the inhibition of tubulin polymerization in HepG-2 cells were measured as described previously [37]. HepG-2 cells were incubated in 8-well cell slide (Eppendorf AG, Hauppauge, NY). After treatment for $48 \mathrm{~h}$ at the indicated concentrations of 6b-(E) $(0.3 \mu \mathrm{M})$ and CA-4 $(0.02 \mu \mathrm{M})$, the cells was fixed with $4 \%$ paraformaldehyde, blocked with PBS containing 5\% BSA and incubated with anti- $\alpha$-tubulin-TRITC antibodies (1:500, Abcam Trading Company Ltd., Shanghai, China) and the secondary antibody (goat anti-rabbit IgG, 1:500, ZSGB-BIO Inc., Beijing, China). At the last step, the cells were stained with DAPI. Images of cells were acquired using an Olympus fluorescence microscope with a $20 \times$ objective.

\subsubsection{Tubulin Polymerization Assay}

Tubulin polymerization assay were performed in the light of the fluorescence based tubulin polymerization assay kit's protocol (Cat. \#BK011P, Cytoskeleton Inc., Denver, CO). Simplify, tubulin $(10 \mathrm{mg} / \mathrm{mL})$ containing buffer 1 , tubulin glycerol buffer and GTP stock $(100 \mathrm{mM})$ were incubated with 6b-(E) $(5,20$ and $40 \mu \mathrm{M})$, paclitaxel $(3 \mu \mathrm{M}), \mathrm{CA}-4(3 \mu \mathrm{M})$ and DMSO for $50 \mathrm{~min}$ at $37^{\circ} \mathrm{C}$. The fluorescence increase was monitored every minute for the characterization of tubulin polymerization at $360 \mathrm{~nm}$ excitation wavelength and $460 \mathrm{~nm}$ emission wavelengths by microplate spectrophotometer (Synergy HTX, BioTek Instruments, Inc., Winooski, VT).

\subsubsection{Statistics Analysis}

All the data were shown as mean \pm standard deviation (SD) from at least three separate determinations with three duplicates. Statistical analysis was performed using GraphPad Prism software with the 2-tailed Student $t$-test.

\subsection{Molecular Docking}

All docking analysis was performed by using the Surflex-Dock program in the Sybyl-X 2.0 software (Tripos Inc., St. Louis, MO). The X-ray crystal structure of tubulin protein (PDB ID: 1SA0) was acquired from the RSCB Protein Data Bank (http://www.rcsb.org/pdb). All bound waters and ligands were eliminated from the protein and the polar hydrogen was added to the proteins. Compounds $\mathbf{6 b}-(\mathrm{Z})$ and $\mathbf{6 b}-(E)$ were drawn and optimized automatically in the Sybyl-X 2.0 software, and saved as a mol2 file. Default parameters were used for Docking. The analysis of results was carried out by USCF Chimera software, which was downloaded from http://www.cgl.ucsf.edu/chimera.

\section{Conclusions}

In this work, we constructed a series of novel CA-4 analogues on the cis-double bond containing diphenylethanone, cis-locked dihydrofuran, $\alpha$-substituted diphenylethanone, cyclobutane and cyclohexane. Yet, most compounds exhibited weak cytotoxic activity against HepG2 cells. Unexpectedly, a by-product $\mathbf{6} \mathbf{b}$ (cis-trans isomers) in the preparation of diphenylethanone analogues 
was found to be the most potent cytotoxic agents against $\mathrm{HepG} 2$ cells with $\mathrm{IC}_{50}$ values of less than $0.5 \mu \mathrm{M}$. The two isomers of $\mathbf{6 b}$ both induced cellular apoptosis, significantly arrested cells in the G2/M phase, severely disrupted microtubule network in HepG2 cells. An in vitro tubulin polymerization assay revealed that $6 \mathbf{b}-(E)$ was a dose-dependent and effective inhibitor of the tubulin assembly. In addition, molecular docking showed that two stereoisomers of $\mathbf{6 b}$ bound similarly and efficiently at the colchicine binding site on tubulin well with CA-4 in similar distorted conformations. Although the anticancer activity of all novel compounds did not behave as excellently as CA-4, these results provided fundamental data for new developments of tubulin inhibitors. Additional insight on $\mathbf{6 b}$ will expand our research of olefin modification of CA-4 or isoCA-4 as tubulin polymerization agents.

Supplementary Materials: Supplementary materials can be found at http://www.mdpi.com/1422-0067/21/5/1817/ s1.

Author Contributions: Conceptualization, M.-Y.S. and J.-J.T.; methodology, M.-Y.S., Y.-L.W., H.-R.W. and Q.-R.H.; software, M.-Y.S.; validation, J.-M.G.; formal analysis, Q.-R.H. and Y.-L.W.; investigation, H.-R.W. and T.-C.J.; resources, J.-J.T.; data curation, M.-Y.S. and T.-C.J.; writing—original draft preparation, M.-Y.S.; writing-review and editing, J.-J.T.; supervision, J.-J.T. and J.-M.G.; project administration, Q.-R.H.; funding acquisition, J.-M.G. All authors have read and agreed to the published version of the manuscript.

Funding: This research was funded by the National Natural Science Foundation of China (21542016) and Yangling Demonstration Zone Science and Technology Plan Project (2017NY-07), China.

Acknowledgments: This work was given some technical support by Instrument Shared Platform of Northwest A\&F University.

Conflicts of Interest: The authors declare no conflict of interest.

\section{References}

1. Pettit, G.R.; Singh, S.B.; Hamel, E.; Lin, C.M.; Alberts, D.S.; Garciakendall, D. Isolation and structure of the strong cell growth and tubulin inhibitor combretastatin A-4. Experientia 1989, 45, 209-211. [CrossRef] [PubMed]

2. Hamel, E. Antimitotic natural products and their interactions with tubulin. Med. Res. Rev. 1996, 16, $207-231$. [CrossRef]

3. Woods, J.A.; Hadfield, J.A.; Pettit, G.R.; Fox, B.W.; Mcgown, A.T. The Interaction with Tubulin of a Series of Stilbenes Based on Combretastatin a-4. Brit. J. Cancer 1995, 71, 705-711. [CrossRef]

4. Young, S.L.; Chaplin, D.J. Combretastatin A4 phosphate: Background and current clinical status. Expert Opin. Investig. Drugs 2004, 13, 1171-1182. [CrossRef] [PubMed]

5. Hori, K.; Saito, S. Microvascular mechanisms by which the combretastatin A-4 derivative AC7700 (AVE8062) induces tumour blood flow stasis. Br. J. Cancer 2003, 89, 1334-1344. [CrossRef] [PubMed]

6. Available online: www.mateon.com (accessed on 15 February 2020).

7. Lipeeva, A.V.; Shults, E.E.; Shakirov, M.M.; Pokrovsky, M.A.; Pokrovsky, A.G. Synthesis and Cytotoxic Activity of a New Group of Heterocyclic Analogues of the Combretastatins. Molecules 2014, 19, 7881-7900. [CrossRef]

8. Jin, Y.H.; Qi, P.; Wang, Z.W.; Shen, Q.R.; Wang, J.; Zhang, W.G.; Song, H.R. 3D-QSAR Study of Combretastatin A-4 Analogs Based on Molecular Docking. Molecules 2011, 16, 6684-6700. [CrossRef]

9. Piekus-Slomka, N.; Mikstacka, R.; Ronowicz, J.; Sobiak, S. Hybrid cis-stilbene Molecules: Novel Anticancer Agents. Int. J. Mol. Sci. 2019, 20, 1300. [CrossRef]

10. Schmitt, F.; Gosch, L.C.; Dittmer, A.; Rothemund, M.; Mueller, T.; Schobert, R.; Biersack, B.; Volkamer, A.; Hopfner, M. Oxazole-Bridged Combretastatin A-4 Derivatives with Tethered Hydroxamic Acids: Structure-Activity Relations of New Inhibitors of HDAC and/or Tubulin Function. Int. J. Mol. Sci. 2019, 20, 383. [CrossRef]

11. Tron, G.C.; Pirali, T.; Sorba, G.; Pagliai, F.; Busacca, S.; Genazzani, A.A. Medicinal Chemistry of Combretastatin A4: Present and Future Directions. J. Med. Chem. 2006, 49, 3033-3044. [CrossRef]

12. Nam, N.H. Combretastatin A-4 analogues as antimitotic antitumor agents. Curr. Med. Chem. 2003, 10, 1697-1722. [CrossRef] [PubMed] 
13. Aprile, S.; Del Grosso, E.; Tron, G.C.; Grosa, G. In vitro metabolism study of combretastatin A-4 in rat and human liver microsomes. Drug Metab. Dispos. 2007, 35, 2252-2261. [CrossRef] [PubMed]

14. Nakamura, M.; Kajita, D.; Matsumoto, Y.; Hashimoto, Y. Design and synthesis of silicon-containing tubulin polymerization inhibitors: Replacement of the ethylene moiety of combretastatin A-4 with a silicon linker. Bioorg. Med. Chem. 2013, 21, 7381-7391. [CrossRef]

15. Pang, Y.Q.; Yan, J.; An, B.J.; Huang, L.; Li, X.S. The synthesis and evaluation of new butadiene derivatives as tubulin polymerization inhibitors. Bioorg. Med. Chem. 2017, 25, 3059-3067. [CrossRef] [PubMed]

16. Chen, H.; Li, Y.; Sheng, C.; Lv, Z.; Dong, G.; Wang, T.; Liu, J.; Zhang, M.; Li, L.; Zhang, T.; et al. Design and synthesis of cyclopropylamide analogues of combretastatin-A4 as novel microtubule-stabilizing agents. J. Med. Chem. 2013, 56, 685-699. [CrossRef] [PubMed]

17. Ty, N.; Pontikis, R.; Chabot, G.G.; Devillers, E.; Quentin, L.; Bourg, S.; Florent, J.C. Synthesis and biological evaluation of enantiomerically pure cyclopropyl analogues of combretastatin A4. Bioorg. Med. Chem. 2013, 21, 1357-1366. [CrossRef]

18. Zhou, P.; Liu, Y.; Zhou, L.; Zhu, K.; Feng, K.; Zhang, H.; Liang, Y.; Jiang, H.; Luo, C.; Liu, M.; et al. Potent Antitumor Activities and Structure Basis of the Chiral beta-Lactam Bridged Analogue of Combretastatin A-4 Binding to Tubulin. J. Med. Chem. 2016, 59, 10329-10334. [CrossRef]

19. Theeramunkong, S.; Caldarelli, A.; Massarotti, A.; Aprile, S.; Caprioglio, D.; Zaninetti, R.; Teruggi, A.; Pirali, T.; Grosa, G.; Tron, G.C.; et al. Regioselective Suzuki coupling of dihaloheteroaromatic compounds as a rapid strategy to synthesize potent rigid combretastatin analogues. J. Med. Chem. 2011, 54, 4977-4986. [CrossRef]

20. Pirali, T.; Busacca, S.; Beltrami, L.; Imovilli, D.; Pagliai, F.; Miglio, G.; Massarotti, A.; Verotta, L.; Tron, G.C.; Sorba, G.; et al. Synthesis and cytotoxic evaluation of combretafurans, potential scaffolds for dual-action antitumoral agents. J. Med. Chem. 2006, 49, 5372-5376. [CrossRef]

21. Assadieskandar, A.; Amini, M.; Ostad, S.N.; Riazi, G.H.; Cheraghi-Shavi, T.; Shafiei, B.; Shafiee, A. Design, synthesis, cytotoxic evaluation and tubulin inhibitory activity of 4-aryl-5-(3,4,5trimethoxyphenyl)-2-alkylthio-1H-imidazole derivatives. Bioorg. Med. Chem. 2013, 21, 2703-2709. [CrossRef]

22. Wang, Z.; Yang, Q.; Bai, Z.; Sun, J.; Jiang, X.; Song, H.; Wu, Y.; Zhang, W. Synthesis and biological evaluation of 2,3-diarylthiophene analogues of combretastatin A-4. Med. Chem. Commun. 2015, 6, 971-976. [CrossRef]

23. Simoni, D.; Grisolia, G.; Giannini, G.; Roberti, M.; Rondanin, R.; Piccagli, L.; Baruchello, R.; Rossi, M.; Romagnoli, R.; Invidiata, F.P.; et al. Heterocyclic and phenyl double-bond-locked combretastatin analogues possessing potent apoptosis-inducing activity in HL60 and in MDR cell lines. J. Med. Chem. 2005, 48, 723-736. [CrossRef] [PubMed]

24. Li, Y.H.; Zhang, B.; Yang, H.K.; Li, Q.; Diao, P.C.; You, W.W.; Zhao, P.L. Design, synthesis, and biological evaluation of novel alkylsulfanyl-1,2,4-triazoles as cis-restricted combretastatin A-4 analogues. Eur. J. Med. Chem. 2017, 125, 1098-1106. [CrossRef] [PubMed]

25. Subba Rao, A.V.; Swapna, K.; Shaik, S.P.; Lakshma Nayak, V.; Srinivasa Reddy, T.; Sunkari, S.; Shaik, T.B.; Bagul, C.; Kamal, A. Synthesis and biological evaluation of cis-restricted triazole/tetrazole mimics of combretastatin-benzothiazole hybrids as tubulin polymerization inhibitors and apoptosis inducers. Bioorg. Med. Chem. 2017, 25, 977-999. [CrossRef]

26. Salehi, M.; Amini, M.; Ostad, S.N.; Riazi, G.H.; Assadieskandar, A.; Shafiei, B.; Shafiee, A. Synthesis, cytotoxic evaluation and molecular docking study of 2-alkylthio-4-(2,3,4-trimethoxyphenyl)-5-aryl-thiazoles as tubulin polymerization inhibitors. Bioorg. Med. Chem. 2013, 21, 7648-7654. [CrossRef] [PubMed]

27. Wang, F.; Yang, Z.; Liu, Y.; Ma, L.; Wu, Y.; He, L.; Shao, M.; Yu, K.; Wu, W.; Pu, Y.; et al. Synthesis and biological evaluation of diarylthiazole derivatives as antimitotic and antivascular agents with potent antitumor activity. Bioorg. Med. Chem. 2015, 23, 3337-3350. [CrossRef]

28. Xu, Q.; Wang, Y.; Xu, J.; Sun, M.; Tian, H.; Zuo, D.; Guan, Q.; Bao, K.; Wu, Y.; Zhang, W. Synthesis and Bioevaluation of 3,6-Diaryl-[1,2,4]triazolo[4,3-b] Pyridazines as Antitubulin Agents. ACS Med. Chem. Lett. 2016, 7, 1202-1206. [CrossRef]

29. Messaoudi, S.; Treguier, B.; Hamze, A.; Provot, O.; Peyrat, J.F.; De Losada, J.R.; Liu, J.M.; Bignon, J.; Wdzieczak-Bakala, J.; Thoret, S.; et al. Isocombretastatins a versus combretastatins a: The forgotten isoCA-4 isomer as a highly promising cytotoxic and antitubulin agent. J. Med. Chem. 2009, 52, 4538-4542. [CrossRef] 
30. Tréguier, B.; Hamze, A.; Provot, O.; Brion, J.-D.; Alami, M. Expeditious synthesis of 1,1-diarylethylenes related to isocombretastatin A-4 (isoCA-4) via palladium-catalyzed arylation of N-tosylhydrazones with aryl triflates. Tetrahedron Lett. 2009, 50, 6549-6552. [CrossRef]

31. Stocker, V.; Ghinet, A.; Leman, M.; Rigo, B.; Millet, R.; Farce, A.; Desravines, D.; Dubois, J.; Waterlot, C.; Gautret, P. On the synthesis and biological properties of isocombretastatins: A case of ketone homologation during Wittig reaction attempts. Rsc Adv. 2013, 3, 3683-3696. [CrossRef]

32. Aziz, J.; Brachet, E.; Hamze, A.; Peyrat, J.F.; Bernadat, G.; Morvan, E.; Bignon, J.; Wdzieczak-Bakala, J.; Desravines, D.; Dubois, J.; et al. Synthesis, biological evaluation, and structure-activity relationships of triand tetrasubstituted olefins related to isocombretastatin A-4 as new tubulin inhibitors. Org. Biomol. Chem. 2013, 11, 430-442. [CrossRef] [PubMed]

33. Rasolofonjatovo, E.; Provot, O.; Hamze, A.; Rodrigo, J.; Bignon, J.; Wdzieczak-Bakala, J.; Desravines, D.; Dubois, J.; Brion, J.D.; Alami, M. Conformationnally restricted naphthalene derivatives type isocombretastatin A-4 and isoerianin analogues: Synthesis, cytotoxicity and antitubulin activity. Eur. J. Med. Chem. 2012, 52, 22-32. [CrossRef] [PubMed]

34. Renko, D.; Provot, O.; Rasolofonjatovo, E.; Bignon, J.; Rodrigo, J.; Dubois, J.; Brion, J.D.; Hamze, A.; Alami, M. Rapid synthesis of 4-arylchromenes from ortho-substituted alkynols: A versatile access to restricted isocombretastatin A-4 analogues as antitumor agents. Eur. J. Med. Chem. 2015, 90, 834-844. [CrossRef] [PubMed]

35. Soussi, M.A.; Provot, O.; Bernadat, G.; Bignon, J.; Wdzieczak-Bakala, J.; Desravines, D.; Dubois, J.; Brion, J.D.; Messaoudi, S.; Alami, M. Discovery of azaisoerianin derivatives as potential antitumors agents. Eur. J. Med. Chem. 2014, 78, 178-189. [CrossRef]

36. Rasolofonjatovo, E.; Provot, O.; Hamze, A.; Rodrigo, J.; Bignon, J.; Wdzieczak-Bakala, J.; Lenoir, C.; Desravines, D.; Dubois, J.; Brion, J.-D.; et al. Design, synthesis and anticancer properties of 5-arylbenzoxepins as conformationally restricted isocombretastatin A-4 analogs. Eur. J. Med. Chem. 2013, 62, 28-39. [CrossRef]

37. Song, M.Y.; Cao, C.Y.; He, Q.R.; Dong, Q.M.; Li, D.; Tang, J.J.; Gao, J.M. Constructing novel dihydrofuran and dihydroisoxazole analogues of isocombretastatin-4 as tubulin polymerization inhibitors through [3+2] reactions. Bioorgan. Med. Chem. 2017, 25, 5290-5302. [CrossRef]

38. Skehan, P.; Storeng, R.; Scudiero, D.; Monks, A.; McMahon, J.; Vistica, D.; Warren, J.T.; Bokesch, H.; Kenney, S.; Boyd, M.R. New colorimetric cytotoxicity assay for anticancer-drug screening. J. Natl. Cancer Inst. 1990, 82, 1107-1112. [CrossRef]

39. Simoni, D.; Romagnoli, R.; Baruchello, R.; Rondanin, R.; Rizzi, M.; Pavani, M.G.; Alloatti, D.; Giannini, G.; Marcellini, M.; Riccioni, T.; et al. Novel combretastatin analogues endowed with antitumor activity. J. Med. Chem. 2006, 49, 3143-3152. [CrossRef]

40. Tang, J.J.; Fan, G.J.; Dai, F.; Ding, D.J.; Wang, Q.; Lu, D.L.; Li, R.R.; Li, X.Z.; Hu, L.M.; Jin, X.L.; et al. Finding more active antioxidants and cancer chemoprevention agents by elongating the conjugated links of resveratrol. Free Radic. Biol. Med. 2011, 50, 1447-1457. [CrossRef]

41. Dong, S.; Tang, J.-J.; Zhang, C.-C.; Tian, J.-M.; Guo, J.-T.; Zhang, Q.; Li, H.; Gao, J.-M. Semisynthesis and in vitro cytotoxic evaluation of new analogues of 1-O-acetylbritannilactone, a sesquiterpene from Inula britannica. Eur. J. Med. Chem. 2014, 80, 71-82. [CrossRef]

42. Tang, J.J.; Dong, S.; Han, Y.Y.; Lei, M.; Gao, J.M. Synthesis of 1-O-acetylbritannilactone analogues from Inula britannica and in vitro evaluation of their anticancer potential. Med. Chem. Comm. 2014, 5, 1584-1589. [CrossRef]

(C) 2020 by the authors. Licensee MDPI, Basel, Switzerland. This article is an open access article distributed under the terms and conditions of the Creative Commons Attribution (CC BY) license (http://creativecommons.org/licenses/by/4.0/). 